UDK 272-732.3“1869/1870”(091)

272-9"18”

Pregledni rad

Primljeno: 27. srpnja 2020.

Prihvaćeno za objavljivanje: 21. prosinca 2020.

\title{
PRVI VATIKANSKI KONCIL U PRIGODI 150. GODIŠNJICE NJEGOVA ZAVRŠETKA
}

\author{
Željko TOLIĆ \\ Katolički bogoslovni fakultet Sveučilišta u Splitu \\ Ul. Zrinsko-Frankopanska 19, 21 000, Split \\ zupaslivnoimotsko@gmail.com
}

\begin{abstract}
Ovaj rad obrađuje Prvi vatikanski koncil. Podijeljen je dva poglavlja. U prvom, koji je naslovljen »Hod prema koncilu« autor govori o događajima koji su prethodili Koncilu: proglašenje dogmatske definicije o Bezgrešnom začeću BDM, objava enciklike Quanta cura i popratnog dokumenta Syllabus, ideja o sazivanju Koncila i njegova najava, zatim neposredna priprava za Koncil $i$ naposljetku rasprave uoči Koncila. U drugom poglavlju, s naslovom »Početak $i$ rad Koncila«, najprije se donosi izvanjski okvir Koncila, a zatim se obrađuje početak Koncila. Nakon toga govori se o dvjema koncilskim konstitucijama Dei Filius $i$ Pastor aeternus, kao i o njihovoj sadržajnoj strukturi. Na kraju se osvrće na Starokatoličku crkvu, koja je nastala kao plod neslaganja s odlukama Prvoga vatikanskog koncila.
\end{abstract}

KLJUČNE RIJEČI: Pio IX., Koncil, komisije, konstitucije, dogma, Crkva.

\section{Uvod}

Prvi vatikanski koncil, prema katoličkom računanju 20. ekumenski, nije došao neplanirano. Već je, naime, bilo prošlo više stoljeća između dvojice rimskih prvosvećenika Katoličke crkve, Pavla III. (1534. - 1549.) i Pija IX. (1846. - 1878.), koji su svaki u svoje vrijeme sazvali ekumenske koncile. Prvi je bulom Laetare Jerusalem 19. studenoga 1544. sazvao Tridentinum, a potonji bulom Aeterni Patris 29. lipnja 1868. Vaticanum primum. Tridentski je imao nekoliko razdoblja i u prekidima je trajao 18 godina, dok Prvi vatikanski koncil nije trajao ni godinu dana, točnije od prosinca 1869. do listopada 1870. Od završetka prvoga (1563.) do početka drugoga (1869.) prošlo je 306 godina tijekom kojih su se dogodile brojne i značajne promjene. To je uviđao i Pijov prethodnik, papa Grgur XVI. (1831. - 1846.), koji je također razmišljao o zazivanju koncila, ali je iz raznoraznih razloga odustao od te zamisli. No, koncilska je nužnost bila sve očitija. Pio IX. je to jasno uviđao i, nakon diskretnih razgovora na tu temu, odvažio se sazvati koncil. Po mjestu održavanja nazvan je 'vatikanski', a po redoslijedu koncila održanih u Vatikanu bio je 'prvi'. 
Iako dovršava sintezu tridentske ekleziologije jer je doveo do pojašnjenja papine uloge u Crkvi, Prvi vatikanski je, zbog njegova neočekivanog prekida, u mnogim drugim aspektima ipak ostao nedorečen. No, taj će 'hendikep' potaknuti novi razvojni proces, koji će svoj puni izričaj doživjeti devedesetak godina kasnije, na Drugome vatikanskom koncilu (1962. - 1965.). Osim po definiciji papine nezabludivosti i primata nad cijelom Crkvom, plod prvog koncila održanog u Vatikanu je i jasna afirmacija katoličkih načela spram brojnih »zala« modernog doba koja su, na krilima Francuske revolucije, nastavljena i u 19. stoljeću kroz razne liberalne težnje i događaje. Svojim definicijama i konstitucijama Prvi vatikanski koncil je odgovorio na vjerske probleme 19. stoljeća, a poglavaru Katoličke crkve, oslobođenu balasta svjetovne vlasti nakon gubitka Crkvene Države, pribavio takav moralni ugled kakvo je papinstvo rijetko kada imalo.

\section{Hod prema Koncilu}

\subsection{Dogma o Bezgrě̌nom začeću BDM}

Jedan od značajnih događaja koji je prethodio Prvome vatikanskom koncilu nedvojbeno je proglašenje dogmatske definicije o Immaculata Conceptio Mariae (Bezgrešnom začeću Blažene Djevice Marije) 1854. godine. Naime, uslijed sve opasnijih agitacija revolucionarne 1848. godine, u Rimu je ubijen predsjednik vlade u Crkvenoj Državi, umjereno liberalni grof Pellegrino Rossi (15. studenoga 1848.). Bio je to uvod u događaje koji su slijedili jedan za drugim: ustanici su opsjedali papinsku palaču na Quirinalu zahtijevajući sazivanje ustavotvorne skupštine i objavu rata Austriji, dok su kardinali i ostali prelati bili izloženi raznim pritiscima i zastrašivanjima. U tako uzavrelim okolnostima Pio IX. je, devet dana nakon Rossijeva ubojstva, napustio Rim 24. studenoga te se, preobučen u običnog svećenika, u diplomatskoj kočiji bavarskog veleposlanika Karla von Spaura sklonio u Gajetu, utvrdu na obali Tirenskoga mora, koja se nalazila u sastavu Kraljevstva Obiju Sicilija. Tu je, pod zaštitom napuljskoga kralja Ferdinanda II. Burbonskoga (1830. - 1859.), ostao 18 mjeseci. ${ }^{1}$ Iz egzila je na čelo vlade u Crkvenoj Državi imenovao svoga državnog tajnika, kardinala Giacoma Antonellija (†1876.), koji će više od dva desetljeća upravljati vatikanskom politikom. ${ }^{2}$

1 John KELLY, Vite dei Papi. Le biografie degli uomini che guidarono 2000 anni di storia della Chiesa, Piemme, Casale Monferrato, 1995., str. 516; Claudio RENDINA, I papi. Storia e segreti, Newton \& Comtpton editori, Roma, 1983., str. 768; August Bernhard HASLER, Come il papa divenne infalibile. Retroscena del Concilio Vaticano I (1870), Claudiana Editrice, Torino, 1983., str. 98.

2 Kardinal Antonelli, s nadimkom »talijanski Richelieu« i »crveni papa«, bio je vrlo spretan i pragmatičan homo politicus. Nakon što su rimski ustanici proglasili Rimsku Republiku i dokinuli Crkvenu Državu, Antonelli je vjerovao da se potonja može ponovno uspostaviti samo izvanjskom intervencijom. Stoga je, po njegovu savjetu, Pio IX. iz egzila zatražio pomoć od katoličkih država nakon čega su francuske postrojbe u ljeto 1849. porazile Rimsku republiku i ponovno uspostavile Crkvenu Državu i papinsku vlast u Rimu: Papa se, nakon 18 mjeseci boravka u egzilu, vratio u Rim 12. travnja 1850. S povratkom u Rim uslijedila je i promjena kursa: političku brigu za Crkvenu Državu papa je prepustio kardinalu Antonelliju, koji će idućih 25 godina upravljati političkom sudbinom Svete stolice. Od tada pa nadalje politika Pija IX. u velikoj je mjeri bila pod utjecajem kardinala Antonellija, koji se odlučio za politiku oštrog kursa prema politički angažiranim krugovima u Rimu. U brojnim pregovorima i pokušajima usklađivanja stavova Crkvene Države s načelima laicizma i liberalizma, koja su zastupali tadašnji vodeći talijanski političari, Antonelli je uporno ponavljao "non possumus", izraz koji je na koncu prihvatio i sam papa. Usp. Carlo FALCONI, Il Cardinale Antonelli: Vita e carriera del Richelieu italiano nella chesa di Pio IX, Mondadori, Milano, 1983. 
Boravak u egzilu potencirao je kod pape radikalan obrat koji je bio od odlučujuće važnosti za daljnja tri desetljeća njegova pontifikata. ${ }^{3}$

Prvi u nizu znakova papina obrata i novog smjera upravo je spomenuta dogmatska definicija. Naime, papa je svoj spas iz buntovnog Rima pripisivao Majci Božjoj te je smatrao svojom dužnošću promovirati njezino čašćenje, koje je išlo u smjeru proglašenja spomenute dogme, koja je u Zapadnoj Crkvi i u Istočnoj Crkvi imala dugu tradiciju. Budući da je otpočetka bio sklon proglašenju te dogme, Pio IX. je već 1. lipnja 1848. osnovao posebno teološko povjerenstvo (gremium theologorum) koje se bavilo razradom te ideje. No, boravak u egzilu znatno je ubrzao započeto djelo tako da je na blagdan Svijećnice 1849. potpisao encikliku Ubi primum, koju je preko tadašnjih nuncijatura poslao »ad totum episcopatum mundi«, s namjerom da o tome čuje mišljenje opće Crkve. Papa je u enciklici zamolio katoličke biskupe da mu odgovore na sljedeće pitanje: »Kakvom je pobožnošću vaš kler i vjernici prožet prema začeću Blažene Djevice Marije, i kako je raspoložen da Sveta stolica odluči o toj stvari, a poglavito želimo znati što vi, časna braćo, osjećate o toj stvari i što prema svojoj izvrsnoj mudrosti želite? $\aleph^{4}$ Od 603 upitana biskupa, na papin je upit pozitivno odgovorilo 546 biskupa: samo nekoliko njih bilo je protiv, a 36 »juxta modum «. ${ }^{5}$ Takav ishod bio je dovoljan razlog da Pio IX. svečano objavi bulu Ineffabilis Deus 8. prosinca 1854. godine. U toj buli i dogmatskoj definiciji, u čijoj su formulaciji uglavnom sudjelovali isusovci, papa, izjavljuje: »određujemo da je nauk koji drži da je Blažena Djevica Marija u prvom času svoga začeća, posebnom milosti i povlasticom svemogućega Boga, radi zasluga Isusa Krista, Spasitelja ljudskoga roda, sačuvana od svake

3 Uvjeren u razornu snagu ideja proisteklih iz Francuske revolucije (1789.), koje su snažno nadahnjivale europsku i rimsku revolucionarnu 1848., u potpunosti se vratio na kurs svoga prethodnika te se neumoljivo upustio u borbu protiv svjetovno orijentiranog liberalizma, u kojem je vidio samo razarajuće tendencije. Usp. Raymund KOTTJE - Bernd MOELLER, Ekumenska povijest Crkve, sv. 3: Novi vijek i moderno doba, Teološki fakultet Matija Vlačić Ilirik, Zagreb, 2008., str. 156.

4 Vincenzo SARDI, La solenne definizione del dogma dell'Immacolato Concepimento di Maria SantissimaAtti e Documenti, vol. I, Roma, 1904., str. 573.

5 Henricus DENZINGER - Adolfus SCHÖNMETZER, Enchiridion symbolorum, definitionum et declarationum de rebus fidei et morum, Herder, Barcinone - Friburgi Brisgoviae - Romae, 361976., str. 560 (dalje: DS); Srećko DRAGOŠEVIĆ, »Prvi vatikanski sabor (uz stogodišnjicu)«, Crkva u svijetu, god. 5, br. 1, Split, 1970., str. 56; A. B. HASLER, Come il papa divenne infalibile, str. 158. U tom je kontekstu zanimljivo trokratno izvješće koje je tadašnji nunciji u Beču Michele Viale-Prelà (1838. - 1845. u Münchenu, 1845. - 1855. u Beču), mjerodavan i za hrvatske biskupije u sklopu Habsburške Monarhije, poslao Državnom tajništvu Svete stolice. U prvom nuncijevu pismu (7. studenoga 1849.), koje šalje tadašnjem još uvijek protajniku Državnog tajništva Svete stolice kardinalu Giacomu Antonelliju, nuncij piše kako biskupi austrijske carevine »iako pristaju uz pobožno mišljenje o Bezgrešnom začeću, ipak izražavaju sumnju u prikladnost da se ta pia sentenza uzdigne na razinu dogme«. U drugom pismu (22. prosinca iste godine) isti piše istome »da se biskupi ove Monarhije pokazuju neskloni« prema dogmatskoj definiciji te smatraju da bi bilo prikladnije da se to 'pobožno mišljenje' (pia opinione) proglasi načelom vjere. U trećem pismu (27. siječnja 1850.) Viale-Prelà piše Antonelliju o istoj stvari, ali nešto podrobnije, i veli kako biskupi misle da se »takva izjava postavlja kao motiv još većeg razdjeljenja između protestanata i katolika, i više kao smetnja za povratak onih prvih u krilo Crkve«. No čini se da su ta nuncijeva pisma bila više odraz njegova osobnog stava, nego mišljenje hrvatskih biskupa, što uostalom pokazuju i njihove izravne izjave podrške Svetom Ocu u pogledu dogmatske definicije Bezgrešnog začeća BDM. Usp. Ratko PERIĆ, »Molbe hrvatskih biskupa za dogmu o Bezgrešnom Začeću Marijinu«, Zbornik radova: Štovanje Bogorodice u Hrvata $u$ XIX. i XX. stoljeću, Adalbert REBIĆ (ur.), Kršćanska sadašnjost, Zagreb, 1990., str. 33-37; R. KOTTJE - B. MOELLER, Ekumenska povijest Crkve, str. 157. 
ljage istočnoga grijeha, od Boga objavljen, i zato treba da ga svi vjernici čvrsto i stalno vjeruju $\ll^{6}$.

Tim činom papa je manifestirao svoju vrhovnu učiteljsku vlast te ex cathedra i ex sese, neovisno od biskupâ i koncila, proglasio vjersku istinu. Molba nekolicine biskupa da se u definiciji spomene i njihova potvrda bila je odbijena. Taj papin čin uzburkao je brojne duhove te se postavilo pitanje: U kojoj je mjeri rimski prvosvećenik osobno, bez suglasnosti koncila, ovlašten donositi vjerske istine? Neposrednog odgovora nije bilo, ali je ostala činjenica da se s definicijom Immaculata Conceptio Mariae na crkvenoj sceni i u njezinoj praksi pojavila papinska nepogrešivost, činjenica koju će 'ultramontanisti' od tada stalno potencirati i neumorno propagirati, kako s propovjedaonica tako i preko tiska. U svakom slučaju, ta odluka rimskog prvosvećenika, kojom je dao svoj doprinos katoličkoj mariologiji, kod mnogih je izazvala ganuće, a kod pojedinca i konkretno nadahnuće slijedom kojega je Luigi Poletti († 1869.), arhitekt iz Modene, na Španjolskom trgu (Piazza Espagna) u Rimu 1857. projektirao stup BDM - »Bezgrešne« (Colonna dell'Immacolata) visok 11,81 m, na čijem se vrhu uzdiže brončani kip Bezgrešne, pred koji papa svake godine na svetkovinu Bezgrešnog začeća polaže cvijeće, a rimski narod iskazuje štovanje, dok je Franz Joseph Rudigier († 1884.), biskup u Linzu, odlučio u čast Bezgrešnom začeću Marijinu sagraditi novu katedralu (završenu 1924.). ${ }^{7}$

\subsection{Enciklika Quanta cura $i$ Syllabus}

Deset godina nakon proglašenja dogme Bezgrešnog začeća BDM uslijedio je novi pretkoncilski događaj. Upravo na svetkovinu Bezgrešnog začeća BDM, 8. prosinca 1864., Pio IX. objavio je encikliku Quanta cura. Uz nju je, kao popratni dio enciklike, svim biskupima dostavio i spis pod nazivom Syllabus, koji je sadržavao popis 80 glavnih »modernih zabluda«, među kojima: racionalizam (koji je za filozofiju i teologiju zahtijevao apsolutnu neovisnost od crkvenog učiteljstva), moderni liberalizam, indiferentizam (za kojega su sve religije bile jednake), panteizam, naturalizam, socijalizam, komunizam, masoneriju, galikanizam, zablude o kršćanskom braku, negiranja koja su se odnosila na papinsku svjetovnu vlast itd. Iako su pojedine od tih zabluda bulom Qui pluribus 9. studenoga $1846 .{ }^{8}$ već bile osuđene, papa ih je u Syllabusu ponovo naveo i sve ih zajedno, u bloku, osudio. ${ }^{9}$

$6 »[\ldots]$ auctoritate Domini nostri Iesu Christi, beatorum Apostolorum Petri et Pauli ac Nostra declaramus, pronuntiamus et definimus, doctrinam, quae tenet, beatissimam Virginem Mariam in primo instanti suae conceptionis fuisse singulari omnipotentis Dei gratia et privilegio, intuitu meritorum Christi Iesu Salvatoris humani generis, ab omni originalis culpae labe praeservatam immunem, esse, a Deo revelatam atque idcirco ab omnibus fidelibus firmiter constanterque credendam «, DS, str. 561-562. Svečanom proglašenju dogme prisustvovala su 54 kardinala i 140 biskupa, među kojima i (samo) jedan od hrvatskih biskupa, Urban Bogdanović, biskup europski, apostolski administrator skopske nadbiskupije. Usp. S. DRAGOŠEVIĆ, Prvi vatikanski sabor, str. 56; R. PERIĆ, Molbe hrvatskih biskupa, str. 37.

7 Josef LENZENWEGER et al., Storia dela Chiesa cattolica, San Paolo, Cinisello Balsamo (Milano), ${ }^{32002 .,}$ str. 595-596.

8 Bula Qui pluribus u: DS, str. 556-559.

9 Usp. Roger AUBERT, »Il pontificato di Pio IX (1846-1878)«, Storia della Chiesa (diretta da J. B. Duroselle - E. Jarry), vol. XXI/1, Edizioni Paoline, Torino, 1990., str. 383-407; Jean Yves LACOSTE et al., Povijest teologije, Kršćanska sadašnjost, Zagreb, 2013., str. 294. 
Iako Syllabus nije imao nikakvu dogmatsku vrijednost, ${ }^{10}$ a nije bio ni na razini stilističke svečanosti kojom je napisana Quanta cura, ipak je on, a ne enciklika (koja je posve ostala u njegovoj sjeni i, izvan crkvenih krugova, gotovo nezapažena), uzburkao javnost kao nijedan papinski dokument do tada. ${ }^{11}$ Njegovom su objavom posebno bili uznemireni liberalni krugovi, uključujući i tzv. »liberalne katolike«, ${ }^{12}$ koji su to okvalificirali kao poziv na rat protiv moderne civilizacije. Strah i nedoumica što ih je taj dokument izazvao diljem europskog kontinenta mogli bi se sažeti u pitanje: Što će biti ukoliko papa pojedine dijelove ili pak čitavi taj dokument proglasi dogmom?

Budući da su liberalne snage u svim europskim državama shvatile Syllabus ne kao legitiman papin čin u cilju očuvanja temeljnih kršćanskih istina od razornih filozofskih tendencija i zamjenskih ideologija, već kao zadiranje na područja političkog i društvenog života koja nisu u nadležnosti Crkve i Rimske kurije, došlo je do opće mobilizacije. Liberalni su krugovi shvatili Syllabus kao znak za borbu te su posvuda, poglavito u Francuskoj, gdje je rasprava vođena osobitom žestinom, reagirali odgovarajućom oštrinom. ${ }^{13}$

$\mathrm{U}$ tako napetom i polariziranom ozračju - u kojem se naravno sudaralo s nadnaravnim, znanstveno s vjerskim, a crkveno s društvenim i obratno ${ }^{14}$ - bilo je potrebno uložiti puno truda kako bi se razjasnile sve nedoumice i ublažila oštrina tog rimskog dokumenta, s jedne, te objasnilo kako se katoličanstvo u tom dokumentu ne promeće u neprijatelja intelektualnog ljudskog napretka, s druge strane. ${ }^{15}$ U Francuskoj se te zadaće prihvatio ugledni orleanski biskup Fèlix Antoine-Philibert Dupanloup (1802. - 1878.) koji je, da primiri duhove, godinu dana nakon objave Syllabusa objavio knjižicu pod nazivom La Convention du 8 Décembre. Suivie d`une Lettre au Journal des Débats u kojoj je iznio svoj komentar. Stavljajući teze Syllabusa u njihov izvorni kontekst, orleanski je biskup znatno ublažio oštrinu rimskog dokumenta i time u velikoj mjeri otklonio strahovanja koja su prožimala liberalne krugove. ${ }^{16}$ Međutim, istodobno je djelovao i cijeli niz ultramontanističkih autora

${ }^{10}$ O tome: Lucien CHOUPIN, Valeur des décisions doctrinales du Saint-Siège, Paris, 31929., str. $119-157$.

11 R. AUBERT, Il pontificato di Pio IX, str. 398.

12 O liberalnim katolicima i »katoličkom liberalizmu, koji je za cilj imao prilagodbu tradicionalne kršćanske vjere načelima suvremenih sloboda koje je iznjedrila Francuska revolucija, kao i o njegovu preteči i gorljivom promicatelju, katoličkom svećeniku, filozofu i političkom teoretičaru Feliceteu Robertu La Mennaisu $(\dagger$ 1854.)«, usp. Andrea Maria ERBA - Pier Luigi GUIDUCCI, Storia della Chiesa. Una storia di famiglia, Editirice Elle Di Ci, Torino, 1989., str. 501, 506; Giacomo MARTINA, Storia della Chiesa, Istituto superiore di scienze religiose, Roma, 1980., str. 368-373; Jacques GADILLE, »Libertà pubbliche. Questione sociale«, Storia del Cristianesimo. Religione-Politica-Cultura, vol. 11, Edizioni Borla, Roma, 2003., str. 27-50.

${ }^{13}$ U kampanju se uključio i francuski dvor: Charles Louis Napoleon Bonaparte, odnosno car Napoleon III. (1852. - 1870.), nećak znatno slavnijega strica Napoleona I. (1805. - 1814.), zabranio je objavu enciklike, a time i Syllabusa, u Francuskoj. Usp. R. AUBERT, Il pontificato di Pio IX, vol. XXI/1, str. 399.

14 Niko IKIĆ, »Ravenski dokument i Pastor Aeternus. Dva dokumenta - dva svijeta - jedan izazov«, Vrhbosnensia, god. 17, br. 1, Sarajevo, 2013., str. 141.

15 R. KOTTJE, B. MOELLER, Ekumenska povijest Crkve, str. 174.

${ }^{16}$ Najavljena 23 siječnja 1865., a u prodaju puštena tri dana kasnije, Duponloupova je knjižica razgrabljena u samo dva sata. Tri tjedna kasnije izišlo je novo izdanje u 100000 primjeraka, a ubrzo je prevedena i na druge jezike. O uspjehu knjižice orleanskog biskupa, među ostalim, svjedoče i pisma zahvale trojice nuncija (u Lisabonu, Münchenu i Beču) nunciju u Parizu, kao i samom autoru, ali i brojnih biskupa, točnije njih 630, koji su od Amerike do Oceanije uputili autoru pisma zahvale, odajući mu priznanje da je tako umješno izrazio njihove misli i osjećaje. Svoj komentar na komentar orleanskog biskupa dao je i papa, koji je jednom svom prijatelju u povjerenju kazao: »Shvatio je i protumačio dokument u pravom smislu«. Usp. R. AUBERT, Il pontificato di Pio IX, vol. XXI/1, str. 401. 
koji su, za razliku od orleanskog biskupa, tumačili Syllabus na širokoj osnovi, prikazujući ga pritom čak i nepogrešivim. ${ }^{17} \mathrm{Uz}$ isusovce, koji su djelovali preko njihove rimske revije La Civiltà Cattolica, jedan od tadašnjih najistaknutijih ultramontanističkih pisaca nedvojbeno je bio dinamični publicist Louis Veuillot (1813. - 1883.), glavni urednik dnevnih novina L'Univers, koji je u svojim svakodnevnim objavama spretno iskorištavao Syllabus protiv »katoličkih liberalaca« ${ }^{18}$ Budući da se papa o njegovim komentarima, kao ni kod Dupanloupove knjižice, nije javno izjašnjavao, moglo se pomisliti da je on time izabrao via media, bez naginjanja na ijednu stranu. ${ }^{19}$

Strah, pojačana napetost i zabrinutost u liberalnim krugovima postali su tim veći kad je Pio IX. najavio sazivanje ekumenske skupštine - Prvog vatikanskog koncila.

\subsection{Začetci i razrada ideje o Koncilu i njegova najava}

Prva sondiranja o sazivu koncila započela su 6. prosinca 1864., dva dana prije objave enciklike Quanta cura. Naime, nakon redovite sjednice Kongregacije za bogoštovlje papa je, nakon što su sa sjednice izišli svi koji nisu bili kardinali, upitao prisutne o svrsishodnosti sazivanja ekumenskog koncila. Isto je pitanje kasnije postavljeno i ostalim članovima kardinalskog kolegija. Papina želja da nakon tri stoljeća sazove koncil bila je više nego očita. Od te ga ideje nisu odvratili ni brojni i negativni komentari i polemike koje je izazvao Syllabus. Dapače, uvjeren u ispravnost stvari, Pio IX. čvrsto je nakanio dvama prethodnim događajima (dogmi o Bezgrešnom začeću i Syllabusu) pridružiti i treći - ekumenski koncil. Tako bi, prema njegovoj zamisli, dogma o Bezgrešnom začeću BDM, Syllabus i koncil predstavljali organsku cjelinu i odgovor Crkve »protiv tolikih zala koji pritišću Crkvu « ${ }^{20}$. Iako su bili zasebni i odijeljeni jedan od drugoga, sva ta tri događaja je ipak, gledano u cjelini, povezivala ista misao i nakana: učiniti protiv teorijskog i praktičnog racionalizma 19. stoljeća ono što je Tridentski koncil učinio protiv protestantizma 16. stoljeća. ${ }^{21}$

Nakon prikupljenih mišljenja, što je potrajalo nekoliko mjeseci, ideja o koncilu počela se i konkretizirati. U ožujku 1865. godine samo nekoliko mjeseci nakon objave Syllabus, Pio IX. je imenovao Predpripravnu komisiju, nazvanu »Upravna i posebna kongregacija za poslove budućeg koncila«. Isprva ju je sačinjavalo pet, a zatim devet kardinala iz Rimske kurije. $^{22}$

\footnotetext{
${ }^{17}$ Iako su ultramontanisti u Španjolskoj, Italiji, Engleskoj, Irskoj, i prije objave Syllabusa pridobili za sebe veći dio katolika, u godinama nakon njegove objave oni su još više napredovali, osobito u Francuskoj i Njemačkoj. U otporu protiv liberalnih vlada katolici su se sve jače vezali uz papu i Rimsku kuriju, a manjini (tj. liberalnim katolicima), koja je željela uspostaviti ravnotežu, sve je više izmicalo tlo pod nogama. Usp. R. KOTTJE - B. MOELLER, Ekumenska povijest Crkve, str. 174-175.

${ }_{18} \mathrm{Na}$ istoj misaonoj platformi djelovali su i Veuillotovi istomišljenici izvan Francuske: engleski rimokatolički obraćenik William George Ward (1812. - 1882.), protivnik liberalnog katolicizma, branitelj papine vlasti, pristaša dogme o papinoj nepogrešivosti i urednik Dublin Review, kao i njegov sunarodnjak Herbert Vaughan (1832. - 1903.), urednik The Tableta. Usp. A. B. HASLER, Come il papa divenne infalibile, str. 61.

19 S. DRAGOŠEVIĆ, Prvi vatikanski, str. 56-57.

${ }^{20}$ R. KOTTJE, B. MOELLER, Ekumenska povijest Crkve, str. 176.

${ }^{21}$ R. AUBERT, »Il pontificato di Pio IX (1846-1878)«, Storia della Chiesa (diretta da J. B. Duroselle - E. Jarry), vol. XXI/2, Edizioni Paoline, Torino, 1990, str. 478-479.

22 Radeći na projektu budućeg Koncila, Predpripravna je komisija (potajno) sakupljala prijedloge za koncilske teme: komunicirala je s tridesetak europskih biskupa (11 Talijana, 9 Francuza, 7 Španjolaca, 5 Austroouga-
} 
Nakon formiranja te komisije uslijedila je i javna obznana koncila. Dana 29. lipnja 1867., prigodom proslave 1800. godišnjice mučeništva apostolskih prvaka sv. Petra i Pavla, papa je u nazočnosti brojnih crkvenih prelata i vjernika najavio koncil kojim, prema papinim riječima, želi pružiti potrebnu utjehu protiv tolikih zala modernog doba koji su se nadvili nad Crkvom. ${ }^{23}$

Godinu dana nakon najave, Pio IX. je, ponovo na blagdan apostolskih prvaka Petra i Pavla, bulom Aeterni Patris 29. lipnja 1868. zazvao koncil, a kao službeni početak naznačen je blagdan Bezgrešnog začeća BDM, 8. prosinca 1869. ${ }^{24}$ Bula o sazivanju ujedno je bila i pozivnica za Koncil na koji su pozvani kardinali, rezidencijalni i naslovni biskupi, poglavari redovničkih redova, opati nullius (tj. opati neovisni o biskupu: abbas nullius dioecesis), poglavari monaških kongregacija. Svi su imali pravo glasa, kao i na Tridentskom koncilu. ${ }^{25}$ Prije objave bule, na Predpripravnoj komisiji raspravljalo se je li, prema običaju prethodnih ekumenskih zajedanja, uputno na Koncil pozvati i poglavare i upravitelje država (popolorum principes et moderatores). Razmotrivši sve okolnosti, na koncu se ipak zaključilo da bi, za razliku od prošlih vremena kada su sacerdotium i imperium djelovali povezano, sada to praktički bilo nemoguće, zapravo neizvedivo, jer su se političke i društvene okolnosti znatno izmijenile te su u mnogim europskim državama njihovi poglavari bili na suprotnoj strani. ${ }^{26}$ Stoga je u buli izostavljen izričit poziv svjetovnim vlastima, no vrata ipak nisu bila posve zabravljena: ostavljena je, naime, mogućnost sudjelovanja na vlastitu inicijativu.

Što se pak tiče odijeljenih Crkava, pravoslavne i protestantskih, tu dvojbe nije bilo, jer je s bulom o sazivanju koncila jednima i drugima upućen breve s pozivom za sudjelovanje na Koncilu. Međutim, neki ishitreni i netaktični potezi tu su inicijativu kompromitirali te je ona jednostavno propala. Naime, sam ton pisma, koje je poslano istočnim biskupima, bio je odveć tvrd i neprikladan, a uz to je, prije nego što je i poslano carigradskom patrijarhu, pismo već bilo objavljeno u novinama, što ga je dodatno kompromitiralo. Sve su te

raca), da bi 1866. proširila suradnju i na neke istočne biskupe. Uz vjerske i disciplinske teme, kao i nezaobilaznu temu o odnosu između Crkve i države, sedam biskupa predložilo je da se Koncil pozabavi i temom papine nezabludivosti. Usp. Piere Thomas CAMELOT et. al., I concili ecumenici, Queriniana, Brescia, 2001., str. 335; Hubert WOLF, »Storia della Chiesa cattolica nel secolo 'lungo' (XIX), dal 1789 al 1918«, Storia ecumenica della Chiesa, vol. 3: Dalla Rivoluzione francese al 1989 (a cura di R. Kottje - B. Moeller - Th. Kaufmann - H. Wolf), Queriniana, Brescia, 2010., str. 162 .

${ }^{23}$ Giacomo MARTINA, Pio IX (1876-1878), Pontificia Università Gregoriana, Roma, 1990., str. 140.

${ }^{24}$ Osim što podsjeća na neke središnje točke katoličke vjere, poglavito na djelo Isusova otkupljenja ljudskoga roda koje Crkvi trajno uprisutnjuje, te naglašava potrebu suočavanja s raznim nedaćama koje pritišću Crkvu, bula kao službeni dokument, s obzirom na program Koncila, ne donosi nikakvu konkretnu naznaku koncilskih tema o kojima će se raspravljati, a pogotovo ne temu o papinoj nezabludivosti.

${ }^{25}$ Postavilo se pitanje apostolskih delegata. Nemali broj je smatrao kako oni, iako biskupi, ali bez naslova, ne bi trebali sudjelovati na Koncilu. Naime, mnoga područja diljem svijeta bila su misijska te su izravno ovisila o Kongregaciji za širenje vjere (Congregatio de propaganda fide), osnovane 1622. radi uređenja misijskog djelovanja Katoličke crkve, koja je u ta područja slala delegate. Oni se formalno ne bi mogli smatrati naslovnim biskupima. Ipak, na koncu je to pitanje nadiđeno i apostolski delegati su, kao i drugi sudionici s pravom glasa, uvršteni među koncilske oce. Usp. Umberto DELL'ORTO - Saverio XERES, Mmanuale di storia della Chiesa, vol. 4: L'epoca conteporanea. Dalla Rivoluzione francese al Vaticano II e alla sua recezione (1789-2005), Morcelliana, Brescia, 2017., str. 177.

26 Primjerice: talijanski kralj bio je izopćen, Austro-Ugarska Monarhija imala je antiklerikalnu vladu, dok su u drugim državama popolorum principes pripadali masonskim krugovima i ložama. Usp. P. TH. CAMELOT et al., I concili ecumenici, str. 339. 
nesmotrenosti (ne)opravdano poslužile istočnim biskupima kao izlika da Rim ne drži do njihova dostojanstva tako da se nisu ni pojavili na Koncilu. Sličnu je sudbinu doživjelo i pismo upućeno protestantima, koje se uz poziv na Koncil istodobno poticalo i na povratak u zajedništvo s Katoličkom crkvom, za što bi Koncil bio najpogodniji trenutak, što su protestanti okvalificirali kao provokaciju. Uz navedeno, stvar je dodatno opteretila i odluka Kongregacije Sv. oficija (Congregatio S. Officii) od 17. studenoga 1869., koja je odbacila ideju o osnivanju posebne komisije koja bi se tijekom Koncila bavila nekatolicima, osobito anglikancima. ${ }^{27}$

\subsection{Neposredna priprava: komisije i Pravilnik}

Nedugo nakon najave Koncila uslijedila su tri pripremna koraka: osnivanje koncilskih komisija, popuna njihovih članova te izrada koncilskog Pravilnika.

S najavom Koncila Predpripravna je komisija, u dogovoru s papom, oformila novih pet komisija, koje su imale zadaću izraditi nacrte (sheme) za buduće koncilske dekrete i spriječiti nepotrebna ponavljanja do kojih je dolazilo na Tridentskom koncilu, gdje se izgubilo dosta dragocjenog vremena upravo zbog manjkavosti preliminarnih radova. No, što se tiče popune ili izbora članova/konzultora u komisijama, stvari nisu bile najsretnije jer je njihova popuna bila izrazito jednostrana i čvrsto u rukama Talijana i kurijalnih prelata. Međutim, nakon protesta pojedinih biskupa koji su u Rimu uživali veliki ugled, krug je proširen pa su u pripremne komisije uključeni i predstavnici drugih škola, odnosno netalijanski stručnjaci (teolozi, pravnici, povjesničari) ${ }^{28}$ Unatoč tomu što u tim komisijama nisu sudjelovala neka doista zvučna imena toga doba, kao što su engleski kardinal John Henry Newman (1801. - 1890.) ili njemački profesor Joseph Ignaz von Döllinger (1799. 1890.), ${ }^{29}$ njihovu su odsutnost uspješno nadomjestile druge kompetentne osobe, kao što su würzburški profesori Franz Hettinger i Joseph Hergenröther (prefekt Vatikanskog arhiva),

${ }^{27}$ U. DELL'ORTO - S. XERES, Mmanuale, str. 176; Guido ZAGHENI, L'età contemporanea. Corso di storia della Chiesa - IV, Edizioni San Paolo, Cinisello Balsamo (Milano), 1996., str. 140-141.

${ }_{28}$ Posebno je izrazit bio protest koji je kardinalu i državnom tajniku Antonelliju uputio praški nadbiskup i kardinal Friedrich von Scwarzenberg (1809. - 1885.), nakon čije su intervencije u pripremne komisije uključeni također i pojedini stručnjaci iz inozemstva. Učinkovito je djelovao i nadbiskup u Mainzu, Wilhelm Emmanuel von Ketteler (1811. - 1877.). On je preko nuncija u Münchenu Pier Francesca Meglia isposlovao da se u koncilske komisije, kao Consultor concilii, uključi Karl Joseph von Hefele (1809. - 1893.), profesor u Tübingenu i pisac brojnih djela iz crkvene povijesti, naročito s temom koncila, a zatim biskup u Rottenburgu. Usp. A. B. HASLER, Come il papa divenne infalibile, str. 64-65.

${ }^{29}$ Prvi je bio pozvan, ali je odbio sudjelovati iznalazeći razne izgovore, koji su skrivali njegovu poteškoću suradnje s drugima na velikoj skupštini, ali još više njegovo nepovjerenje u smjer kojim je Rimska kurija vodila Crkvu. Drugi pak, Döllinger, prepošt kanoničke crkve sv. Kajetana u Münchenu i ugledni profesor povijesti na Teološkom fakultetu u Münchenu, već je izvjesno vrijeme stajao na proturimskim pozicijama. S tih je stajališta u augsburškim novinama Allgemeine Zeitung, pod pseudonimom Janus, objavio pet članaka protiv papine nezabludivosti, osobito u njezinim maksimalističkim oblicima, a neke je članke protiv ultramontanista (poglavito ekstremističkih teza koje je zastupao Veuillot) i papinstva objavio i u bečkim liberalnim novinama Neue freie Presse. Sve te objave (augsburške i bečke) Döllinger je u srpnju 1869. spojio u knjigu pod naslovom Der Papst und das Konzil (Papa i Koncil). Usp. Karl BIHLMEYER - Hermann TUECHLE, Storia della Chiesa, vol 4: L'epoca moderna, Morcelliana, Brescia, 91990., str. 208, 241; Joseph LORTZ, Storia della Chiesa considerata in prospettiva di storia delle idee, vol. II: Evo moderno, Edizioni Paoline, Cinisello Balsamo (Milano), 1987., str. 429; S. DRAGOŠEVIĆ, Prvi vatikanski, str. 59. 
dvojica njemačkih isusovca Johannes Franzelin i Clemens Schrader, talijanski isusovac Giovanni Perrone, koji je pridonio u pripremi dogmatske definicije o Bezgrešnom začeću BDM, a bio je i autor vrlo raširene Praelectiones dogmaticae, koja je propagirala papinsku nezabludivost do ekstremnih oblika, i još mnogi drugi. ${ }^{30}$

U pripremi Koncila radilo je pet komisija u kojima je sudjelovalo 114 konzultora, od kojih 76 Talijana. ${ }^{31}$ Bile su to teološka komisija, komisija za crkvenu disciplinu, za redovništvo, za misije i Crkve istočnog obreda te crkveno-politička komisija.

- Teološka komisija imala je 24 člana, a predsjedao joj je kardinal Luigi Maria Bilio (1826. - 1884.). Za nju su bila rezervirana najvažnija pitanja. Komisija je svoj rad započela preuzimanjem nekih dijelova iz Syllabusa. Najvažnije točke, uključujući i one koje su se odnosile na papu i njegove prerogative, trebale su predstavljati nacrte koncilskih konstitucija.

- Komisija za crkvenu disciplinu imala je 19 članova, a na čelu joj je bio kardinal Prospero Caterini (1795. - 1881.). S osvrtom na disciplinske dekrete Tridentskog koncila, komisija je isprva predviđala rješavanje samo onih pitanja koja su se odnosila na život svećenika, pastoralno djelovanje i biskupsku službu, ali su se ubrzo nametnule i druge važne teme: crkveno bračno zakonodavstvo i stvaranje jedinstvenog katekizma za cijelu Katoličku crkvu.

- Komisija za redovništvo imala je 12 članova, a predsjedao joj je kardinal Giuseppe Andrea Bizzarri (1802. - 1877.). Njezina je zadaća bila proučiti različite probleme crkvenih redova i kongregacija. Izradila je 18 nacrta o kojima se nije raspravljalo, ali je ta građa u obilnoj mjeri poslužila u kasnijoj kodifikaciji.

- Komisija za misije i Crkve istočnog obreda imala je 17 članova, a vodio ju je kardinal Alessandro Barnabò (1801. - 1874.). Komisija je opširno raspravljala o primjeni dekretâ Tridentskog koncila na Istočne crkve te izradila nacrte konstitucija o misijama, obredima i o izvanrednom djelitelju sakramenta potvrde.

- Crkveno-politička komisija, kojoj je predsjedao jedini netalijanski kardinal, Nijemac Karl-August Graf von Reisach (1800. - 1869.), suočila s opširnim programom - o odnosima između Crkve i države, upravljanju crkvenim dobrima, sjemeništima, pokrajinskim sinodama, braku, vjerskoj toleranciji i bogoštovlju - iz čega je proizišlo 18 provizornih nacrta, ali se ni o jednom nije raspravljalo; vjerojatno zato da se ubrza rad Koncila, a zasigurno i zbog iznenadne smrti kardinala Reisacha početkom koncilskog zasjedanja. ${ }^{32}$

Nakon dvogodišnjeg rada i brojnih zajedničkih sastanaka, koji su se odvijali svakih dva do tri tjedna, komisije su izradile oko 65 nacrta za buduće koncilske dekrete. Međutim, raspravljalo se samo o njih šest (Circa fidem, De Ecclesia Christi, De matrimonio christiano, Circa disiplinam ecclesiasticam, Circa ordines regulares, Circa res Ritus orientalis et Apostolicas Missiones), a proglašena samo su dva (Dei Filius i Pastor Aeternus). Također je bio odobren, ali ne i proglašen, jedinstveni katekizam za cijelu Crkvu. ${ }^{33}$

\footnotetext{
${ }^{30}$ J. Y. LACOSTE et al., Povijest teologije, str. 295.

${ }^{31}$ G. ZAGHENI, L'età contemporanea, str. 138. Uz članove komisija, organizacijska struktura Koncila obuhvaćala je i druge potrebne službe: bilježnike, brojače glasova, tumače i stenografe.

${ }^{32}$ Hubert JEDIN, Breve storia dei concili, Herder - Mocelelliana, Roma - Brescia, 81989., str. 172-173; G. ZAGHENI, L'età contemporanea, str. 138-139.

${ }^{33}$ Klaus SCHATZ, Storia della Chiesa, vol. 3: Epoca moderna II, Queriniana, Brescia, 1995., str. 70.
} 
S obzirom na Pravilnik Koncila, koji je po uzorku na Pravilnik Petog lateranskog koncila (1512. - 1517.) uglavnom uredio Nijemac Hefele, on je objavljen desetak dana prije početka Koncila, točnije 27. studenoga 1869. godine. Za razliku od Tridentskog koncila, na kojem su koncilski oci slobodno odlučivali o modus procedendi, vatikanski je Pravilnik nametnut odozgo, odnosno papinim apostolskim pismom Multiplices, koje je koncilskim ocima predočeno samo tjedan dana prije početka Koncila, točnije 2. prosinca 1869. godine. ${ }^{34}$ Kako je već spomenuto, Pravilnik je koncipiran u smislu bržeg odvijanja rada, bez gubljenja vremena u diskusijama o proceduri, o 'precedenciji' i drugim pitanjima, koja su više puta došla do izražaja u Tridentu. Ukratko: težio je za bržim i apsolutnim prihvaćanjem pripremljenih nacrta.

Što se tiče predlaganja tema, dakako da je papa imao rezervirano pravo predlagati Koncilu teme i pitanja za raspravu, dok su koncilski oci svoje zahtjeve mogli predstaviti posebnoj komisiji - De postulatis, čije je članove (njih 24) izravno imenovao Sveti Otac. Nacrti su se proučavali na općim kongregacijama/sjednicama. U slučaju da nisu bili prihvaćeni, tada bi nova redakcija bila povjerena jednom od četiriju odbora (za vjeru, disciplinu, redovnike $i$ istočne obrede). Svaki od tih odbora imao je 24 člana, koje su na početku Koncila izabrali koncilski oci. Nakon preuređenja, nacrti bi se ponovno vraćali na opću kongregaciju, gdje bi ih se iznova proučavalo i prihvaćalo i zatim svečano proglašavalo na svečanim sjednicama, koje su se održavale u papinoj nazočnosti.

\subsection{Rasprave prije početka Koncila}

Najava Koncila je u liberalnim krugovima pobudila određeni nemir i pojačala napetost. Oštre rasprave između njih i ultramontanista ( $\mathrm{tj}$. tradicionalista), koje su se vodile nakon objave Syllabusa, ponovno su oživjele u pretkoncilsko vrijeme te su na površinu, među ostalim, izbacile i pitanje papine nezabludivosti.

Sve je započelo 1867. godine, kada je u isusovačkoj reviji La Civiltà Cattolica objavljen članak koji je od katolika tražio trostruki doprinos sv. Petru: novčani (financijska potpora), krvni (obrana Crkvene Države) i intelektualni (podlaganje papinoj nepogrešivosti). ${ }^{35} \mathrm{U}$ tom smislu, 28. lipnja 1867., u predvečerje proslave 1800. obljetnice mučeništva apostolskih prvaka Petra i Pavla, biskup iz Regensburga Ignatius von Senestréy (1818. - 1906.) i biskup iz Westminstera Henry Edward Manning (1808. - 1892.) obvezali su se na grobu sv. Petra da će učiniti sve što bude u njihovoj moći kako bi se donijela dogmatska definicija o papinoj nezabludivosti. ${ }^{36}$

Raskol između katoličkih liberala i ultramontanista još se više produbio kada je, ponovno u spomenutoj isusovačkoj reviji 6. veljače 1869., objavljen »Dopis iz Francuske« u kojem se tvrdilo kako se francuski katolici žarko nadaju da će budući koncil prihvatiti ne samo nauk izložen u Syllabusu, nego da će koncilski oci, prosvijetljeni Duhom

\footnotetext{
${ }^{34}$ R. KOTTJE - B. MOELLER, Ekumenska povijest Crkve, str. 176.

${ }_{35}$ Carlo PICCIRILlO, »Un nuovo tributo a San Pietro«, La Civiltà Cattolica, br. 10, Roma, 1867., str. 640651; J. LENZENWEGER et al., Storia della Chiesa cattolica, str. 596.

${ }^{36}$ K. SCHATZ, Storia della Chiesa, str. 72.
} 
Svetim, dogmu o papinoj nezabludivosti donijeti per acclamationem. ${ }^{37}$ Tako je papina nezabludivost postala dominirajuća tema u francuskom crkvenom i društvenom životu. U crkvenom okruženju o njoj se raspravljalo na pokrajinskim sinodama i učestalo pisalo u biskupskim okružnicama, dok su je u društvenom miljeu neumorno propagirali dinamični Veuillot i njegovi istomišljenici. I dok je većina francuskih katolika bila za tu dogmatsku definiciju, manjina ju je smatrala beskorisnom, čak i štetnom za Crkvu. U tome su posebno prednjačila dvojica istaknutih prelata toga vremena: već spominjani orleanski biskup Dupanloup i Henri Louis Charles Maret (1885. - 1884.), biskup i dekan Teološkog fakulteta na Sorboni.

Dupaloup je u studenome 1869., dakle neposredno pred početak Koncila, objavio knjižicu pod naslovom Obrevations sur la controverse soulevée relativement à la définition de l'infaillibilité au prochain concile, u kojoj je iznio razloge zbog kojih smatra da je ta definicija nepotrebna i neprikladna. Tako navodi: jer je Crkva 18. stoljeća živjela bez te dogme i bila joj je dovoljna vjera u nezabludivost opće Crkve; jer bi izazvala velike teškoće na ekumenskom području te bi otežala odnose s Istočnim crkvama i protestantima; jer ne bi imala jednodušan pristanak Crkve, što bi se izravno kosilo s Tridentskim koncilom, koji je utvrdio da se definicija ne može donijeti osim konsenzusom sviju; jer je u Tridentu ispuštena kako bi se izbjegle napetosti u papinsko-biskupskom suodnosu; jer nisu bili jasni uvjeti koji su činili locutio i locutio ex cathedra; jer s njezinim izglasavanjem ne bi bilo lako objasniti neke povijesne činjenice iz crkvene povijesti i papinstva; jer bi stvorila teškoće u odnosima s europskim vladama te bi zasjenila papinu duhovnu vlast. Stoga, tvrdi na koncu orleanski biskup, treba čvrsto ostati na trima glavnim temeljima: nezabludivosti Crkve, papinu primatu i neprekidnosti crkvene predaje.

$\mathrm{S}$ druge strane, u javnost je s knjižicom naslovljenom $D u$ concile générale et de la paix religieuse izišao i umjereni galikanist Maret. Iznoseći svoje stavove i neslaganje s definicijom o papinoj nezabludivosti, on se referira na sv. Antonina iz Firence (1389. - 1459.) te veli da je papa nezabludiv »utens consilio et requirens adioutorium universalis Ecclesiae«. Nezabludivost, smatra on, nužno pretpostavlja i uključuje suradnju episkopata. ${ }^{38}$

\section{Početak i rad Koncila}

\section{1. Izvanjski okvir Koncila}

Prvi vatikanski koncil je u brojčanom pogledu nadmašio sve prethodne. U usporedbi s prethodnim Tridentskim koncilom, na završetku kojega je bilo prisutno 213 koncilskih

${ }^{37}$ La Civiltà Cattolica, br. 5, 1869., str. 345-352. Autor članka, isprva nepoznat, a kasnije prepoznat kao opat Darras, osim definicije o nepogrešivosti per aclamationem, također je iznio želju mnogih katolika i za proglašenje dogme o Marijinu uznesenju. O Darrasu vidi u: G. MARTINA, Pio IX (1867-1878), str. 154-157.

${ }^{38}$ Iako protivnik definicije o papinoj nezabludivosti, Maret se također distancirao i od onih teoloških mišljenja koja su vrhovnu vlast u Crkvi pripisivala samo episkopatu. U djelu Le Pape et les éveques (1869.) tvrdi da se crkveni autoritet sastoji iz dvaju važnih elemenata: papa i episkopat (prvi je glavni, drugi je podređen prvom). Nezabludivost se nalazi u papi ujedinjenom s biskupima, a ne odijeljenom od njih. Iako je Maret želio upoznati javno mnijenje sa svim dokazima koji se protive papinoj nezabludivosti, dogodilo se upravo suprotno: njegovo je djelo, kao i druge njegove intervencije koje su se protivile nezabludivosti, imalo sasvim suprotan efekt: voda na mlin u prilog papine nezabludivosti. 
otaca (svi su bili Europljani), na Prvom vatikanskom koncilu je broj sudionika bio neusporedivo veći. Od ukupno 1050 katoličkih biskupa, koliko ih je tada bilo u Katoličkoj crkvi, na koncilu je sudjelovalo oko 700 prelata s pravom glasa, koji su prvi put došli sa svih pet kontinenata, s tim da je nakon Uskrsa 1870. godine broj pao na oko 600. Od toga je 245 bilo neeuropskih, 200 Talijana (više od četvrtine), 120 s engleskog govornog područja, dok su na Tridentskom koncilu bila samo četiri biskupa engleskog jezika.

Kao i na drugim koncilima, tako su i na Prvome vatikanskom koncilu postojale razne grupacije/stranke. One nisu bile određene nacionalnim grupacijama, kao primjerice na Konstanzanskom koncilu na kojem se glasovalo per nationem, nego suprotnošću između infalibilista i antiinfalibilista.

S obzirom na prve, koji su ujedno bili i većinska grupacija, oni su okupljali oko 450 koncilskih otaca, podijeljenih u nekoliko skupina: talijanski (osim jedne skupine iz Lombardije - Venecije i opata iz Montecassina), španjolski, mnogi francuski i latinoamerički biskupi. Vodeće osobe te skupine bili su Victor Auguste Dechamps (Mechelen), Manning (Westminster), Luois-Édouard-Frannçois-Desiré Pie (Poitiers), Gaspard Mermillod (Ženeva) i Konrad Martin (Paderborn). Talijani, koji su činili četvrtinu sabornika, bili su znatno inferiorniji i, s izuzetkom njih nekoliko (Guidi, D>Avanzo, Zinelli, Riario, Sforza), gotovo dezorijentirani. U to sivilo uklopio se i kardinal Pecci (budući papa Leon XIII.), koji se na Koncilu nije posebno isticao.

Što se tiče drugih, antiinfalibilista, njih je bilo 150. Pripadali su joj uglavnom svi njemački (njih 17) i austrougarski biskupi (njih 48), pojedini francuski biskupi (od njih 84), neki američki biskupi i istočni patrijarsi. Vodeće osobe te skupine bili su već spomenuti Hefele, Rauscher, Ketteler, Dupanloup, Maret, Schwarzenberg, Joseph Othmar von Rauscher (Beč), Paul Melchers (Köln), dok je najborbeniji, bez premca, bio bosansko-srijemski biskup (unaprijed: đakovački) Josip Juraj Strossmayer.

Uz većinsku i manjinsku grupaciju, postojala je i treća, neutralna ili umjerena grupacija, koju su predvodili Henri-Marie-Gaston Boisnormand de Bonnechose (biskup u Rouenu) i Martin John Spaldinga (biskup u Baltimoru). Ta grupacija, kojoj su pripadali apostolski vikari (njih oko 70), nije imala velikog utjecaja te je smatrana »masom za manevriranje«. U većini slučajeva njezini su pripadnici završili među infalibilistima.

Što se tiče glasovanja, koncilski su oci svoj votum izražavali na tri načina: slaganje se izražavalo s placet, uvjetno slaganje s placet iuxta modum (što je podrazumijevalo i prijedlog promjene), a neslaganje s non placet.

$\mathrm{Na}$ Koncilu su održane četiri javne (svečane) sjednice i 89 tzv. generalnih kongregacija. Službu generalnog tajnika Koncila obavljao je Joseph Fessler, biskup u austrijskom St. Pöltenu. ${ }^{39}$

\footnotetext{
${ }^{39}$ Informacije o izvanjskom okviru Koncila vidi u: J. LORTZ, Storia della Chiesa, 430; U. DELL'ORTO - S. XERES, Mmanuale, str. 177-178; G. ZAGHENI, L'età contemporanea, str. 142-143; R. KOTTJE B. MOELLER, Ekumenska povijest Crkve, str. 177; H. JEDIN, Breve storia dei concili, str. 142-143; K. BIHLMEYER - H. TUECHLE, Storia della Chiesa, str. 241.
} 


\subsection{Težak početak}

Koncil je, kako je i predviđeno, otvoren na blagdan Bezgrešnog začeća 8. prosinca 1869. godine. Započeo je svečanom ceremonijom u bazilici sv. Petra, nakon koje se u desnom transeptu bazilike započelo s koncilskim zasjedanjima.

Prvi dokument koji je Koncil uzeo u razmatranje bio je nacrt De fide catholica (O katoličkoj vjeri), koji je za koncilsku raspravu izradio isusovački kardinal Johannes Baptist Franzelin (1816. - 1886.). Taj nacrt, koji je započinjao riječima: »Pius episcopus servus servorum Dei, sacro approbante concilio ad perpetuam rei memoriam ${ }^{40}$, imao je 18 poglavlja te je, spram racionalističkih zabluda, sadržavao osnove kršćanskog nauka. Bila je to svojevrsna summa theologica koja je težila osvježiti i duhu vremena prilagoditi vjekovno učenje Crkve. No, na šest koncilskih sjednica (od 28. prosinca 1869. do 10. siječnja 1870.) pokazalo se da nacrt ima ozbiljnih nedostataka te da baš i ne odgovara duhu vremena zbog čega je tijekom rasprave doživio brojne i ozbiljne kritike. ${ }^{41}$ Njegovi kritičari, među kojima i Strossmayer, ${ }^{42}$ zamjerali su da je predug i nejasan, odveć teorijski, a premalo pastoralan i ekumenski. Vodstvo Koncila uvažilo je iznesene primjedbe te nacrt vratilo na daljnju doradu. ${ }^{43}$

Dok je povjerenstvo dorađivalo nacrt De fide, koncilski su oci u međuvremenu raspravljali o nacrtu za crkvenu disciplinu (Schema de disciplina ecclesiastica): o biskupima i njihovim dužnostima i obvezama, o generalnim vikarima, biskupskim sinodama, biskupskoj sede vacante, životu i moralnosti klerika itd. Tijekom tih rasprava svoj je govor (drugi po redu) održao i Strossmayer. ${ }^{44}$

${ }^{40}$ Giuseppe ALBERIGIO et al., Conciliorum oecumenicorum decreta, Edizioni Dehoniane, Bologna, 32013, str. 802 (dalje: COD). Koncilski dokumenti na Tridentskom koncilu u pravilu počinju riječima: »Sacrosancta Tridentina synodus«, »Haec sacrosancta oecumenica et generalis synodus« ili pak »Sacrosancta oecumenica et generalis Tridentina synodus« (usp. COD, str. 660, 690, 693). Vatikanska formulacija je drukčija i jasno ističe promjenu gledišta između dvaju koncila.

${ }^{41}$ Upravo ta činjenica da je nacrt konstitucije doživio snažne kritike dokazuje da su teze pojedinih autora (među kojima i već spominjani A. B. Hasler) koje dovode u pitanje slobodu Koncila doista neutemeljene, jer upravo kritike i primjedbe na račun nacrta najbolje su svjedočanstvo da sloboda govora, izjašnjavanja i neslaganja na Koncilu nisu bili zapriječeni, ograničeni ili pak uvjetovani.

${ }^{42}$ Bio je to prvi od četiriju Strossmayerovih govora na Koncilu (30. prosinca 1869.). Uzevši riječ, đakovački je biskup iznio kritiku već na početne riječi (Pius episcopus servus servorum Dei...) tvrdeći da one ističu samo papinski autoritet, a ignoriraju biskupska prava. Predlažući da se umjesto tih riječi primjeni tridentska formula (Sacrosancta oecumenica et generalis synodus in Spiritu Sancto legitime congregata ... koja podjednako uključuje prava pape i biskupa), intervenirao je kopredsjednik Koncila, kardinal Hanibal Capalti (1811. - 1877.), koji je Strossmayera prekinuo te mu predbacio da se udaljava od teme i da nedovoljno poštuje autoritet pape. Nakon te opomene, đakovački je biskup zatim prešao na stil i sadržaj nacrta iznoseći primjedbu da se u njemu racionalizam nepravedno svodi na protestantizam te da je previše tvrd i nedoličan poslanju Crkve. Usp. Andrija SPILETAK, Strossmayer i pape (drugi dio), Đakovo, 1929., str. 3-9; Andrija ŠULJAK, »Biskup Josip Juraj Strossmayer i Prvi vatikanski sabor«, Zbornik radova o Josipu Jurju Strossmayeru, Dobriša SKOK (ur.), HAZU, Zagreb, 1997., str. 66-67. Osim Strossmayera, svoje su mišljenje iznijeli i drugi kritičari. Tako je Thomas Louis Connolly, kapucinski nadbiskup iz Kanade, cinično ustvrdio: »Schema nec resarciendo nec emendandum, sed cum honore sepeliendum «.

${ }^{43}$ Usp. H. WOLF, Storia della Chiesa cattolica nel secolo 'lungo' (XIX), str. 167. Nakon vraćanja na doradu izabrano je povjerenstvo od 24 člana, koje je nacrt potpuno preradilo. Budući da su svi članovi u tom povjerenstvu bili iz redova infalibilista, to nije prošlo bez glasne kritike od strane antiinfalibilista.

${ }^{44}$ Rasprava o nacrtu za crkvenu disciplinu započela je 14. siječnja 1870. Strossmayer je, kao 29. govornik u raspravi došao na red 24. siječnja, prije podneva. Suvereno je i snažno govorio o reformi središnjih crkvenih ustanova, poglavito o reformi Kardinalskog zbora (koji je zamišljao kao senat Crkve sastavljen »iz svih 
No, u to vrijeme, dok se još raspravljalo o disciplinskim temama, došlo je do manje krize koncilskoga rada, koju su izazvala dva problema: akustičke poteškoće u auli i dužina rasprava. S obzirom na akustiku, rasprave su do daljnjega bile prekinute, točnije od 22 . veljače do 18. ožujka 1870., a što se tiče dužine rasprava, Koncil je donio novi Pravilnik (22. veljače). Zapravo je »osvježio« početni, u kojemu je od nekoliko izmjena najvažnija bila ona da se ubuduće na zahtjev desetorice koncilskih otaca moglo staviti na glasovanje kraj pojedine rasprave (što se primijenilo samo jedanput, nakon sveobuhvatnog pregleda konstitucije Pastor Aeternus), a za usvajanje je bila dovoljna natpolovična većina. Naime, budući da je početni koncilski Pravilnik bio dosta širok, koncilske su rasprave trajale u nedogled. Da bi to spriječili, voditelji Koncila odlučili su promijeniti Pravilnik i time suziti mogućnost dugih i beskorisnih rasprava. Koncilska manjina je tim činom, kao i kod imenovanja povjerenstva za nacrt De fide, bila ogorčena i jako protestirala, posebno Strossmayer, koji je bez uvijanja novi Pravilnik nazvao »Tumulus sepulturalis« Koncila i slobode govora. Osim što su spriječene duge i beskorisne rasprave, s tom je poslovničkom izmjenom došlo do inauguracije još jedne vrlo značajne stvari: napušteno je, naime, načelo o tzv. »moralnoj jednodušnosti «, na kojem je posebno inzistirala manjina. ${ }^{45}$

\subsection{Dogmatska konstitucija o katoličkoj vjeri Dei Filius}

Nakon što je u međuvremenu povjerenstvo doradilo ili, bolje reći potpuno preradilo nacrt O katoličkoj vjeri, ${ }^{46}$ on je ponovno vraćen u koncilsku aulu, gdje se o njemu raspravljalo od 18. ožujka do 24. travnja 1870. U tom razdoblju (na 33. općoj sjednici koncila) 22. ožujka svoj je govor, kao četvrti govornik toga jutra, održao i đakovački biskup Strossmayer. Bio je to njegov četvrti po redu koncilski govor tijekom kojeg je izazvao burna negodovanja, poslije kojega je sjednica bila zaključena i njezin nastavak zakazan za sljedeći dan. U svom govoru Strossmayer je, nakon što je uputio oštre kritike na uvod nacrta, ukazivao na problem da se u novouređenom tekstu nalaze neke neprimjerene tvrdnje o protestantizmu, osobito kad se tvrdi da je »protestantizam izvor svih pogrešaka i zala«. Zatim je - ustvrdivši da među protestantima u Njemačkoj, Engleskoj i Americi postoji veliko mnoštvo ljudi koji vole »našega Gospodina Isusa Krista« - s prizivom na sv. Au-

\footnotetext{
naroda i narodnosti« čime bi se postiglo veće dobro i poznavanje pravnih i realnih potreba sviju Crkava, a ne samo jedne), o reformi Rimskih kongregacija (koje bi se, prema njemu, trebale više baviti općim pitanjima $i$ dopustiti više slobode biskupima ordinarijima u njihovim biskupijama), te o reformi crkvenog zakonika (što bi, smatrao je Strossmayer, bilo »unum inter opera praeclariora huius Vaticani conciliv). Usp. A. SPILETAK, Strossmayer i Pape, str. 9-15; A. ŠULJAK, Biskup Josip Juraj Strossmayer, str. 68.

${ }^{45}$ Pozivajući se na francuskog redovnika i crkvenog pisca sv. Vinka Lerinskoga († 450.), manjina je načelo o »moralnoj jednodušnosti« - koje se, istini za volju, nije primjenjivalo ni u prošlosti, na prethodnim koncilima - htjela primijeniti kao pravilo za proglašenje neke dogme, jer je smatrala da se samo ono što je moralnom jednodušnošću, oduvijek i kod svih, prihvaćeno kao vjerska istina, može smatrati dogmom ili proglasiti za dogmu. Budući da su prelati iz kruga manjine bili protivni dogmi o papinoj nezabludivosti, to je značilo da moralna jednodušnost ne postoji te da se, slijedom toga, dogma ne može donijeti. No, koncilska većina nije uvažila to manjinsko nastojanje te je novim Pravilnikom odredila da je za proglašenje dogme potrebna većina prisutnih, a ne moralna jednodušnost. Usp. A. ŠULJAK, Biskup Josip Juraj Strossmayer, str. 70-71.

${ }^{46}$ Iako je na njemu radilo cijelo povjerenstvo, ta je preuredba uglavnom bila djelo četvorice stručnjaka: trojice biskupa (Pie, Dechamp i Martin) i jednog redovnika (njemačkog isusovca Josepha Kleutgena).
} 
gustina, kazao: »U zabludi su, u zabludi su, ali su u dobroj vjeri u zabludi; heretici su; heretici, ali ih hereticima nitko ne smatra. $\ll^{47}$

Netom što je Strossmayer izgovorio te riječi, u koncilskoj je auli nastalo negodovanje, žamor i dobacivanje, a predsjedavajući Koncila, kardinal i nadbiskup Ferma Filippo De Angelis (1792. - 1877.), opomenuo je đakovačkog biskupa da se ne služi riječima koje iritiraju i sablažnjavaju neke oce. Strossmayer mu je uzvratio u istom smislu, ali zbog velike buke i žamora njegove se riječi nisu dobro čule ni razumjele. No, očito ga je čuo kopredsjednik Koncila, kardinal Capalti, koji je Strossmayera ponovno prekinuo uz primjedbu da se ne može poreći da su iz protestantizma kao takvog potekle »tolike današnje zablude«. Strossmayer je zahvalio za kardinalovo »razjašnjenje«, ali ga nije uvažio tvrdeći i dalje da među protestantima ima mnoštvo ljudi koji ljube Isusa Krista. Time je ponovno izazvao veliko negodovanje, mrmljanje i zlovolju među koncilskim ocima. Da smiri situaciju, kardinal Capalti ponovno je prekinuo đakovačkog biskupa. Upozorio ga je da se drži onoga što piše u nacrtu te ga zamolio da odustane od takvog govora koji vrijeđa uši većine biskupa. Đakovački biskup je uvažio te opomene, ali ne i posustao s oštrinom svoga govora jer se u nastavku obrušio na izmijenjeni Pravilnik i novi sustav glasovanja. Uviđajući da bi mu tadašnji predsjedavajući Koncila (kardinali De Angelis i Capalti) - što zbog glorifikacije protestanata, što zbog preoštre kritike glasačkog sustava - mogli oduzeti riječ, što se na kraju i dogodilo, đakovački je biskup, stalno prekidan bučnim protestima i negodovanjem koncilskih otaca, ponovno pozvao na »moralno jednodušje«. Jedva da je to uspio i izgovoriti, koncilske kolege su ga zasuli nevjerojatnim nazivima, kao što su »heretik«, »Lucifer« i »drugi Luther«, a čuli su se glasni povici: »Anathema, anathema«, »Napolje s njim«. U tako mučnoj i nadasve užarenoj atmosferi, u kojoj se glasno i bučno tražilo da siđe s pozornice, Strossmayerovi opetovani uzvici »protestiram«, bili su glas vapijućeg u pustinji. Nitko ga nije čuo ni uvažavao. ${ }^{48}$ Đakovački biskup je, istina, izazvao neviđeno komešanje, zlovolju, bijes i srdžbu kod većine koncilskih otaca, ali je njegov nastup i nevjerojatno hrabar govor ipak imao pozitivan učinak. Doveo je do poboljšanja nacrtnog teksta De fide catholica iz kojeg su uklonjene teške i optužujuće riječi o protestantizmu kao »izvoru svih pogrešaka i zala $\aleph^{49}$.

U nastavku zasjedanja rasprave su bile mirnije, bez napetosti i većinsko-manjinskih suprotstavljanja. To je bilo i razumljivo, jer na dnevnom redu nisu bile dogmatske, već ležernije teme, kao što su: je li poželjnije kazati catholica ecclesia ili sancta catholica apostolica ecclesia, kako bi se izbjegao mogući prigovor anglikanaca koji podržavaju tezu o samo jednoj Crkvi podijeljenoj na tri grane (rimokatolička, anglokatolička, grčkopravoslavna). U tako opuštenoj atmosferi i raspravi neki su koncilski oci pošli i dalje te su zahtijevali da Koncil osudi ontologizam (filozofski nazor prema kojemu razum intuitivnom idejom

\footnotetext{
${ }^{47}$ Ioannes Dominicus MANSI, Sacrorum Conciliorum nova, et amplissima colectio, vol. 51, Florentiae-Venetiis-Lipsiae, coll. 42-48 (dalje: MANSI).

48 A. ŠULJAK, Biskup Josip Juraj Strossmayer, str. 71-72. U toj buci i metežu predsjedavajući je Strossmayera najprije upozorio da se drži teme, zatim da siđe s govornice (na što je više puta upozoren zvoncem), i na kraju da šuti. Naposljetku je bio primoran oduzeti mu riječ, unatoč Strossmayerovu ogorčenom prosvjedu.

${ }^{49}$ MANSI, vol. 51, coll. 74-77. Usp. A. SPILETAK, Strossmayer i pape, str. 17-24.
} 
spoznaje beskonačan bitak, a po njemu i sve stvorene stvari) ${ }^{50}$ dok su drugi pledirali za manje strogosti prema tradicionalizmu. ${ }^{51}$

Nakon toga na red je došlo konačno glasovanje o nacrtu O katoličkoj vjeri. I doista, nakon što je na povjerenstvu bio temeljito pročišćen i u koncilskim raspravama dodatno iznijansiran, taj je dokument 24. travnja 1870. jednoglasno, sa 667 glasova, prihvaćen i proglašen kao dogmatska konstitucija Dei Filius. ${ }^{52}$

S obzirom na strukturu, Dei Filius ima četiri dijela: Predgovor (proemimum), četiri poglavlja, 18 kanona (canones) i Zaključak (epilogus). Što se tiče kanona, oni se referiraju na prethodna poglavlja (uz prvo poglavlje: pet kanona, drugo: četiri kanona, treće: šest kanona, četvrto: tri kanona) i svi završavaju s tradicionalnom formulom anathema sit za onoga tko ih ne prihvaća. ${ }^{53}$

U prvom poglavlju (De rerum omnium creatore) govori se o katoličkoj vjeri spram najvažnijih zabluda 19. stoljeća. Te zablude, stoji u konstituciji, proizlaze iz filozofskih nazora koji, proglašavajući autonomiju subjekta, dovode do poricanja ideje o prisutnosti osobnog i transcendentog Boga u ljudskoj povijesti ili pak teže prema radikalnoj preformulaciji te božanske prisutnosti. Korijeni tih zabluda, veli konstitucija, nalaze se u protestantskoj »pobuni« i u teoriji slobodne volje. Koncilski dokument proglašava vjeru u osobnog i transcendentnog Boga koji je, ni na koji način primoran, stvorio svijet »slobodnom voljom«.

U drugom poglavlju (De revelatione) tvrdi se da čovjek svojim razumom iz stvorenih stvari može spoznati Boga, koji je početak i kraj svega stvorenoga, no za jasnu i nepogrešivu spoznaju nadnaravnih istina ljudskom je razumu nužna božanska objava. ${ }^{54} \mathrm{~S}$ tim dogmatskim izjavama Koncil se jasno usprotivio tvrdnjama deizma, apsolutnog racionalizma i tradicionalizma.

Treće poglavlje (De fide) govori o vjeri kao nadnaravnoj kreposti. Čovjek vjeruje u objavljene istine zbog Božjeg autoriteta koji ih otkriva (tj. objavljuje), a ne zbog nutarnje istine

${ }^{50}$ Glavni predstavnik ontologizma bio je Vincenzo Gioberti (1801. - 1852.), talijanski svećenik, filozof, publicist i političar, od kojega i potječe taj termin (1844). U širem značenju, termin označuje postavljanje ontologije kao temeljne filozofske znanosti, odnosno svođenja glavnih filozofijskih problema na ontologijske.

51 Tradicionalizam je tvrdio da pojedinac, odnosno ljudski razum, ne može spoznati metafizičke, religijske i moralne istine izvan neke tradicije. Po tom je učenju praobjava, prenošena tradicijom, jedini izvor vjerske spoznaje. Nastao je u 19. stoljeću u Francuskoj kao reakcija na individualistički racionalizam i skepticizam, a glavni su mu predstavnici bili J de Maistre, L. de Bonald i neko vrijeme F. R. La Mennais. Katolička crkva je osudila tradicionalizam zbog zapostavljanja razuma u vjerskoj spoznaji te zbog miješanja opće i crkvene tradicije.

${ }^{52}$ Među onima koji su dali svoj placet za tu koncilsku konstituciju nije se nalazio i onaj biskupa Strossmayera, koji i nije bio na glasovanju. Namjerno je bio odsutan i time je želio izraziti svoje neslaganje i prosvjed protiv novog koncilskog Pravilnika kojim se za izglasavanje nije tražila moralna jednodušnost, nego natpolovična većina. I dok se u bazilici sv. Petra odvijala svečana ceremonija zbog toga važnog čina, đakovački je biskup bio izvan Vatikana: protestno je šetao ulicom Via del Corso. Usp. G. ZAGHENI, L'età contemporanea, str. 146; A. ŠULJAK, Biskup Josip Juraj Strossmayer, str. 73.

53 Tekst konstitucije u: MANSI, vol. 51, coll. 429-436; DS, str. 587-595; COD, str. 804-811.

$54 »$ Eadem sancta mater Ecclesia tenet et docet, Deum, rerum omnium principium et finem, naturali humanae rationis lumine e rebus creatis certo cognosci posse [...] Huic divinae revelationi tribuendum quidem est, ut ea, quae in rebus divinis humanae rationi per se impervia non sunt, in praesenti quoque generis humani conditione ab omnibus expedite, firma certitudine et nullo admixto errore cognosci possint «, COD, str. 86; DS, str. 588 . 
samih stvari. Vjera, međutim, nije slijepi pristanak, već razumno prianjanje jer se temelji na vanjskim znakovima koji su vjerodostojni, kao što su čuda i proroštva.

Četvrto poglavlje (De fide et ratione) bavi se odnosom vjere i razuma. Odbacuje se apsolutna autonomija razuma koji, suočen s tajnama koje ga nadilaze, može doći do djelomičnog razumijevanja; pa ipak, premda ograničen, on zadržava presudnu ulogu na putu prema vjeri. Nadalje se tvrdi da ne postoje dvije istine niti može biti sukoba između vjere i razuma (fides e ratio inter se dissidere numquam possunt). Neslaganje između znanosti i religije može doći jedino zbog pogrešnog tumačenja vjerskih istina ili pak zbog krive interpretacije u znanosti.

U svakom slučaju, u tadašnjem europskom okruženju koje je na razne načine i pod raznim vidovima bilo nesklono, dapače, neprijateljski nastrojeno prema kršćanskoj vjeri, konstitucija Dei Filius željela je zaštititi čovjekov hod prema Bogu, ne gubeći pritom iz vida bitne čimbenike na tom putu, kao što su: božanska objava, potvrda objavljene riječi od strane crkvenog učiteljstva, prostor savjesti i osobnog razuma svakog pojedinca. U tom smislu, konstitucija se pokazuje kao uravnotežen balast između dogme i znanstvenog istraživanja, između vjere i osobnog iskustva.

\subsection{Konstitucija o Kristovoj Crkvi Pastor aeternus}

Nakon Dei Filius, pred koncilskim se ocima našao nacrt $O$ malom katekizmu. ${ }^{55}$ Budući da je taj nacrt u mnogome odražavao duh Rimske kurije te u tom smislu bio odveć uniformiran i jednostran, a premalo prilagođen mjesnim potrebama i kulturološkim razlikama, koncilski su oci iznijeli brojne objekcije. Unatoč tomu, komisija koja ga je izradila ustrajno je branila svoj uradak i smatrala da je nacrt pogodan za službeno proglašenje. ${ }^{56}$ No, to se ipak nije dogodilo jer se, u kontekstu značajnijih koncilskih tema, rad na katekizmu smatrao tek usputnom dionicom Koncila pa mu zato nije poklonjeno previše vremena.

Da je pitanje katekizma bilo tek usputno, pokazali su i skori koncilski događaji. Naime, komisija De postulatis je 9. veljače 1870. odlučila u Pravilnik rada Koncila umetnuti pitanje papine nezabludivosti ${ }^{57}$ te je u kratkom roku, već 6 . ožujka, o tome predstavljen i

\footnotetext{
${ }_{55} \mathrm{Na}$ temu katekizama održane su četiri sjednice od 29. travnja do 13 svibnja. Na glasovanju za nacrt dekreta o katekizmu ishod je bio slijedeći: 491 placet, 56 non placet te 44 placet juxta modum. Usp. G. ZAGHENI, L'età contemporanea, str. 147.

${ }_{56}$ O nacrtu kao i o primjedbama koncilskih otaca vidi u: MANSI, vol. 51, coll. 536-538, 454-456.

57 Naime, već krajem prosinca 1869. jedna je skupina koncilskih otaca, okupljena oko Senestreya i Manninga, organizirala prikupljanje potpisa s ciljem da se tema o papinoj nezabludivosti nađe na dnevnom redu Koncila. Od otprilike 700 koncilskih otaca ta je skupina zagovornika nezabludivosti prikupila 450 potpisa. No, ni opozicija koja se protivila toj temi nije stajala skrštenih ruku. Praški kardinal i nadbiskup Schwarzenberg je 29. siječnja 1870., uz popratno pismo, predao istoj komisiji (De postulatis) pet molbi koje su potpisala 132 koncilska oca: prva molba, na kojoj se nalazio i Strossmayerov potpis, imala je 46 potpisa austrougarskih i njemačkih biskupa; druga molba sadržavala je 40 potpisa francuskih biskupa; treća 26 potpisa biskupa iz Sjeverne Amerike; četvrta je imala 13 potpisa sirijskih i kaldejskih biskupa; petu molbu potpisalo je sedam talijanskih biskupa. Usp. K. SCHATZ, Storia della Chiesa, str. 72; A. SPILETAK, Strossmayer i pape, str. 25.
} 
poseban nacrt, koji je imao četiri poglavlja. Isprva je taj nacrt bio predviđen kao dodatak 11. poglavlju konstitucije De Ecclesia, koji se odnosio na papin primat. $^{58}$

$\mathrm{S}$ uvrštavanjem u dnevni red Koncila pitanje nezabludivosti rimskog prvosvećenika postalo je goruće pitanje oko kojeg su se lomila koplja, kako na Koncilu tako i izvan njega. Dok je većina bila nepokolebljivo ustrajna da se papina nezabludivost proglasi dogmom, manjina se, nakon što je odbijena njezina molba da se o tome uopće ne raspravlja, tomu protivila i srčano opirala, u čemu su je podržavale i pojedine europske vlade: tako je, primjerice, francuski ministar vanjskih poslova Napoléon Daru (1807. - 1890.) poslao dvije diplomatske protestne 'note' na temu papine nezabludivosti, što su europske liberalne vlade primile sa simpatijom i podržale njegovu diplomatsku intervenciju. No, za Pija IX. to nije bilo od velikog značenja. Nije se previše obazirao što kaže neki nezadovoljni ministar, a i doskorašnji događaji su pokazali da je ispravno postupio jer je Daru nedugo iza toga podnio ostavku (iz razloga koji nisu bili povezani s Koncilom, već s referendumom u Francuskoj), a nova francuska vlada s Oliverom Émilom Ollivierom (1825 - - 1913.) na čelu bila je po tom pitanju posve neutralna. ${ }^{59} \mathrm{~Pa}$ ipak, da bi se ubuduće spriječili slični scenariji, uplitanja, 'političke note' i pritisci, vodstvo Koncila je odlučilo ubrzati rad i pitanje nezabludivosti urgentno riješiti. U protivnom, smatrala je koncilska većina, svako bi otezanje - a to je bilo moguće ukoliko bi se poglavlja De Ecclesia razmatrala jedno po jedno - predstavljalo opasnost.

Tu je opasnost uviđao i papa. Stoga je odlučio anticipirati koncilsku raspravu tako da rasprava $O \mathrm{Crkvi}$, umjesto od prvoga, započne s jedanaestim poglavljem, tj. poglavljem o primatu rimskog biskupa, koje je pretvoreno u nacrt zasebne konstitucije. Ta papina odluka priopćena je koncilskim ocima 29. travnja 1870., ali je rasprava o tome, iz tehničkih razloga, započela 13. svibnja iste godine. Novi nacrt koncilskoj je skupštini predstavio mons. Pie, biskup Poitiersa. Nakon što je od 13. svibnja do 3. lipnja prošao koncilsku raspravu, nacrt je na koncu dobio većinu glasova.$^{60}$ Glavne nedoumice i pitanja koja su se tijekom rasprave pojavila uglavnom su se odnosila na odnos između papine nadležnosti i nadležnosti biskupa. Također se mnogo raspravljalo i o preciznom razjašnjenju područja i dosega papine nezabludivosti te što se o tome može naći u Svetom pismu. U nacrtu je prvi put upotrijebljen izraz per se irreformabilia te se ističe da je riječ samo o jednoj, identičnoj, nezabludivosti pape i Crkve, ali se nije razjasnio točan objekt nezabludivosti.

Nakon toga raspravljalo se o pojedinim poglavljima. U dva dana, 6. i 7. lipnja, na brzinu su pregledani Predgovor i prva dva poglavlja, uz zanimljiv dodatak u Predgovoru, gdje se veli da je episkopat ustanovio Krist. ${ }^{61}$

O trećem se poglavlju raspravljalo na pet sjednica, od 9. do 14. lipnja. Nastupila su 33 govornika, koji su u svojim govorima naglašavali temu zajedništva među Crkvama. U definiranju povlastica rimskog prvosvećenika trebalo je voditi računa o patrijarhalnoj strukturi Crkve. Zapadnom Crkvom upravljao je patrijarh priznat kao vrhovni svećenik (Pontifex

\footnotetext{
${ }^{58}$ K. BIHLMEYER, H. TUECHLE, Storia della Chiesa, str. 242.

59 R. AUBERT, Il pontificato di Pio IX, vol. XXI/2, str. 533-534.

${ }_{60}$ Tijekom rasprave održano je 65 govora i 14 sjednica, koje su u prosjeku trajale četiri sata.

${ }^{61}$ MANSI, vol. 52, Arnhem (Pays-Bas)-Leipzig, 1927., col. 4.
} 
maximus) opće Crkve, ali su i Istočne crkve posjedovale drevnu patrijarhalnu strukturu koju je trebalo uvažavati. ${ }^{62}$

Rasprava o četvrtom poglavlju bila je duža. Trajala je od 15. lipnja do 4. srpnja. U tom je razdoblju održano 14 sjednica i nastupilo 57 govornika, ${ }^{63}$ među kojima i dominikanski teolog iz redova koncilske većine Filippo Maria Guidi, kardinal i nadbiskup Bologne, ${ }^{64}$ koji je 18. lipnja održao svoj govor. Polazeći od teza sv. Antonina iz Firence, Guidi je napravio razliku između pape koji djeluje motu proprio singularis (na vlastitu inicijativu i u svoje ime) i pape utens consilio et requirens adjutorium universalis Ecclesiae, priznajući papi nezabludivost samo u potonjem slučaju. Drugim riječima, umjesto o »osobnoj nezabludivosti«, kardinal Guidi je, da bi donekle udobrovoljio koncilsku manjinu, predlagao tezu $\mathrm{o} »$ nezabludivom učiteljstvu«. ${ }^{65}$

No, udobrovoljavajući manjini, kardinal i nadbiskup Bologne iznenadio je i rasrdio većinu koja se, kao i papa, usprotivila njegovu prijedlogu te i dalje nepopustljivo ostala kod svojih stajališta u pogledu papine nezabludivosti. Nakon Gudija, u iduća dva tjedna, izredali su se još mnogi govornici 'pozicije' i 'opozicije' (većine i manjine), koji su više-manje stereotipno ponavljali već poznate stavove jedne ili druge strane, ${ }^{66}$ a brojni su još čekali na red za svoje govore. No, vruće ljetno razdoblje i poznata rimska sparina bili su nesnosni za jednu i drugu stranu. Budući da u govorima nije bilo nikakvih novosti, već samo stereotipno ponavljanje poznatoga, obje su se strane 4. srpnja međusobno dogovorile da se

${ }^{62} \mathrm{~S}$ tim u vezi zanimljiva je bila intervencija patrijarha Yssefa. Usp. MANSI, vol. 52, coll. 671-676.

${ }^{63}$ Jedan od značajnijih nastupa u toj fazi bio je govor kardinala Rauschera, nadbiskupa Beča. On je istaknuo da ne postoji slučaj nezabludivosti Rimskog biskupa u izricanju dogmatske definicije koji se ne bi obazirao na prethodni, istodobni ili posljedični pristanak Crkava. Za prihvaćanje objavljene Božje riječi dovoljna je moralna sigurnost, a za prihvaćanje uobičajenog nauka Crkve treba imati apsolutnu sigurnost, koja ne proizlazi samo od rimskog biskupa nego i od pristanka Crkava.

${ }^{64}$ Guidi je bio nadbiskup u Bologni, ali svoju nadbiskupsku stolicu nije mogao zaposjesti jer se tomu usprotivila talijanska vlada. O njemu su pojedini autori (primjerice Hasler) tvrdili da bi bio 'figlio del papa', no to je ničim dokazana objeda, tim zlobnija ima li se u vidu da je spomenuti autor (rođen 1937. u švicarskom Aadorfu) gotovo bjesomučno nesklon prema dogmi o papinoj nezabludivosti i, na poseban način, prema Piju IX. No, činjenicu da je Pio IX. doista oštro ukorio Guidija zbog njegova »osobnijeg « govora o nezabludivosti ne može se osporiti. O tome: A. B. HASLER, Come il papa divenne infalibile, str. 23, 84-85; Giuseppe CROCE, »Una fonte importatne per la storia del pontificato di Pio IX e del concilio Vaticano I: i manoscritti di Vincenzo Tizzani«, Archivum historiae pontificiae, br. 23, Roma, 1985., str. 217-345. O papinu ukoru: Isto, str. 275-277.

${ }_{65}$ Tvrdnje dominikanskog kardinala - da papa ne bio nezabludiv ukoliko bi djelovao izolirano i neovisno od Crkve, već samo kad uvažava mišljenje biskupa i tradiciju Crkve - izazvale su nevjericu kod većine koncilskih otaca. I papa je bio vrlo nezadovoljan tom izjavom te je istu večer pozvao Guidija na razgovor i, kako je već rečeno, oštro ga ukorio. Predbacujući Guidiju pozivanje na crkvenu tradiciju, nesmotreno je, u ljutnji, izgovorio: »Ja sam tradicija»; već sutradan je ta papina izjava osvanula u novinama te protumačena u znatno agresivnijem tonu. Što se pak tiče koncilske manjine, ona je bila oduševljena Guidijevim nastupom, do te mjere da su se koncilski oci iz redova manjine počeli međusobno grliti i plakati od oduševljenja jer su mislili da je preko Guidija, koji je slovio kao istaknuti teolog većine, govorila koncilska većina i da je konačno došlo do kompromisnog rješenja. Usp. A. B. HASLER, Come il papa divenne infalibile, str. 83-84; R. AUBERT, Il pontificato di Pio IX, vol. XXI/2, str. 540-542.

${ }^{66}$ Jedan od značajnijih pokušaja s manjinske strane da utječe na većinu bio je pokušaj Kettelera, nadbiskupa Mainza, koji je, oslanjajući se na autoritet dominikanskoga skolastičkog teologa Melchiora Cana († 1560.), zastupao tezu prema kojoj bi papa za neku dogmatsku definiciju ex cathedra trebao upotrijebiti sva sredstva potrebna za razjašnjenje predmeta (Sveto pismo, tradiciju i mišljenje biskupa). Usp. MANSI, vol. 52, coll. 890-899. 
rasprava zaključi. Predsjedavajući Koncila je taj međusobni sporazum dviju strana prihvatio i zaključio raspravu, šaljući komisiji prispjele amandmane za izradu konačne formule ${ }^{67}$ Komisija je razmotrila sve amandmane koje su koncilski oci pismeno podastrli po pitanju nezabludivosti te, više od stotinu prispjelih, usvojila prijedlog kardinala i nadbiskupa Dublina i primasa Irske Paula Cullena (1803. - 1878.), čiji je prijedlog komisija još neznatno poboljšala s vrlo sretnim i uspjelim tehničkim izrazom ex cathedra, koji je komisija kompletirala dugim povijesnim uvodom (koji je uglavnom priredio biskup Martin). ${ }^{68}$

S izrazom ex cathedra, nacrt o papinoj nezabludivosti ponovno je došao pred koncilske oce. U pojašnjenju izraza, kao i cijele stvari oko toga, bio je značajan nastup i komentar Federica Marije Zinellija, biskupa u Trevisu, koji je papinu vlast opisao kao potestas episcopalis, ordinaria, immediata; papinska vlast je istovrsna s biskupskom, s tim što je papina najviša i vrhovna. ${ }^{69}$

Na Zinellijev komentar se 11. srpnja nadovezao Vincenzo Gasser, biskup u južnotirolskom Brixenu. Kao službeni predstavljač konstitucije, on je iznio sadržaj i obilježja nezabludivosti, opisujući je trima pridjevima: osobna, odvojena i apsolutna: ${ }^{70}$

- osobna nezabludivost: ta se povlastica ne primjenjuje samo na Svetu stolicu, kako su željele neke pristaše galikanizma, već na svakog papu koji djeluje u točno preciziranim okolnostima: kad nastupa ex cathedra;

- odvojena ili bolje razlikovna nezabludivost: temelji se na posebnoj pomoći Duha Svetoga i nije istovjetna s onom koja se pridaje općoj Crkvi. Papa je nezabludiv kad definira ono što svi trebaju vjerovati ili odbaciti. Međutim, papa je dužan koristiti se prikladnim sredstvima kako bi točno ispitao i objavio istinu. Ta sredstva su koncili, vijeća kardinala, biskupa, teologa itd. Papa nije izdvojen iz konsenzusa, ali konsenzus nije taj koji daje nezabludivost;

- apsolutna nezabludivost: kad govori o vjeri i moralu, kao vrhovni i opći Otac. Biskupe mora potvrditi Petar, a ne obratno. Odnos s njima mora postojati, ali nije neophodan. U tom kontekstu postaje jasno i razumljivo da su odluke koje proglasi Koncil nepogrešive samo kada ih potvrdi papa.

Dana 13. srpnja održano je glasovanje o cijelom nacrtu, s ishodom: 451 placet, 88 non placet, 62 placet juxta modum. Oko 50 koncilskih otaca nije prisustvovalo sjednici. ${ }^{71}$ Manjina je, dakle, unatoč poboljšanjima u formulaciji i dodatnim objašnjenjima, i dalje ostala nepopustljiva u svojim stavovima.

Papa je bio nezadovoljan ishodom glasovanja. Stoga je na prijedlog nekog talijanskog biskupa, čije je ime nepoznato, dao zadatak kardinalu Biliju da se u tekst nacrta umetnu još neke dodatne riječi koje osuđuju bilo kakve galikanske težnje. Bili je to učinio, upotrijebivši glasovitu formulu ex sese, non autem ex consensu Ecclesiae. ${ }^{72}$

\footnotetext{
${ }^{67}$ R. AUBERT, Il pontificato di Pio IX, vol. XXI/2, str. 542.

68 Isto, str. 544.

${ }^{69}$ MANSI, vol. 52, col. 1103.

${ }^{70}$ Isto, coll. 1204-1230.

${ }^{71}$ P. TH. CAMELOT et al., I concili ecumenici, str. 360; H. JEDIN, Breve storia dei concili, str. 193.

72 Riječ je o dobro promišljenoj formuli koja je eksplicite poništavala partikularne težnje četvrtoga galikanskog članka iz 1682. godine: »Nisi Ecclesiae consensu accesserit«.
} 
Dana 15. srpnja jedna delegacija manjine došla je kod pape na audijenciju te mu obećala da će glasovati za definiciju o papinoj nezabludivosti, ali pod uvjetom da se u nju umetnu riječi testimonio Ecclesiarum innixus. No, od pape su dobili neodređen odgovor. Dva dana kasnije, 17. srpnja, manjina je, prije proglašenja dogme, odlučila napustiti Rim te je o tome pismeno obavijestila papu. ${ }^{73}$

Unatoč tomu, sutradan 18. srpnja u 16 sati, dok je u Rimu bjesnilo strašno nevrijeme (koje su protivnici definicije protumačili kao nebeski znak), Koncil je proglasio dogmatsku konstituciju o Crkvi Kristovoj, koja je po početnim riječima nazvana Pastor aeternus. Na glasovanju je bilo prisutno 535 koncilskih otaca: 533 placet, dvojica non placet (biskup Riccio sa Sicilije i Fitzgerald iz Amerike). Nakon što je papa potvrdio ishod glasovanja, njegove su riječi izazvale toliko oduševljenje među koncilskim ocima da se ono čulo i na Trgu sv. Petra. Dvojica biskupa koji su bili protivni izjavili su nakon toga da se i oni pridružuju novoproglašenoj dogmi, priključivši se zatim zahvalnom hvalospjevu Te Deum, kojim je završila svečanost proglašenja dogme o papinoj nezabludivosti. ${ }^{74}$

\subsubsection{Struktura konstitucije Pastor aeternus}

Konstitucija Pastor aeternus ima predgovor i četiri poglavlja. ${ }^{75} \mathrm{U}$ predgovoru se ističe kako je Vječni pastir i čuvar naših duša, Isus Krist, ustanovio svoju Crkvu u kojoj bi svi vjernici, kao u kući Boga živoga, trebali biti povezani u jednoj vjeri i ljubavi. Prije svoga uzašašća na nebo poslao je apostole u svijet te im pretpostavio blaženoga Petra kao vječno počelo i vidljiv temelj jedinstva. ${ }^{76}$

U prvom poglavlju, koje govori o ustanovi apostolskog primata u blaženom Petru ( $D e$ apostolici primatus in beato Petro institutione), govori se o biblijskom utemeljenju primata, kojega se veže uz Isusove riječi u Mt 16,18-19 (Ti si Petar-Stijena [...] Tebi ću dati ključeve kraljevstva nebeskoga [...]), kao i u Iv 21,16-17 (Pasi jaganjce moje [...] Pasi ovce moje). Stoga se osuđuju (anathema sit) koji bi nijekali da Krist nije postavio Petra za

${ }^{73}$ Pismo je potpisalo 55 koncilskih otaca; ostalih šest, koji su također napusti Koncil, uputili su osobno pismo papi u istom smislu.

74 R. AUBERT, Il pontificato di Pio IX, vol. XXI/2, str. 548-549. Giulio Arrigoni (1806. - 1875), nadbiskup u Lucca, opisao je taj događaj sljedećim riječima: „Nakon potvrde pape (misli se na njegovu nezabludivost, op. a.) svećenici su pljeskali i, sljedeći njihov primjer, svi su prisutni vjernici u Sv. Petru počeli povikivati: »Živio nezabludivi papa. Za to vrijeme bjesnilo je strašno nevrijeme i bljeskovi, munje, voda i gromovi, kao da su najavljivali kraj svijeta. Objavljen je rat između Francuske i Prusije. Tko zna hoćemo li se ponovno sastati?«, navod prema: Michelei MACCARRONE, Il concilio Vaticano I. e il »Giornale« di monsignor Arrigoni, Antenore, Padova, 1966., str. 456. Međutim, nije se posvuda pljeskalo i klicalo papinoj nezabludivosti. Dok je u bazilici sv. Petra vladalo oduševljenje, drugdje su uslijedile protivne reakcije. Naime, liberali i protivnici Crkve su proglašenje dogmatske definicije iskoristili da bi napravili pritisak na europske vlade, slijedom čega su Austrija i Portugal otkazali sklopljene konkordate sa Svetom Stolicom, engleski konzervativni državnik je izjavljivao da je dogma politički veoma opasna (jer vjernici tobože neće znati koga treba slušati), dok je Bismarck u Njemačkoj to iskoristio da bi pojačao pritisak na katolike - znameniti Kulturkampf. O tome vidi u: Josef NEUNER et al., La fede della Chiesa nei documenti del magistero ecclesiastico, Studium, Roma, 1967., str. 285-297.

75 Tekst konstitucije u: COD, str. 811-816; DS, str. 595-601.

$76 »[\ldots]$ beatum Petrum caeteris apostolis praeponens in ipso instituit perpetuum utriusque unitatis principium ac visibile fundamentum «, COD, str. 812; DS, str. 596. 
apostolskog prvaka i vidljivu glavu nad cijelom vojujućom Crkvom, kao i oni koji tumače da je to prvenstvo, odnosno primat, samo prvenstvo časti, a ne istinsko i pravo prvenstvo. ${ }^{77}$ U drugom poglavlju govori se o perpetuizaciji Petrova primata u rimskim prvosvećenicima (De perpetuitate primatus beati Petri in Romani pontificibus). Osuđuju se svi koji negiraju da Petar, po ustanovi Krista Gospodina ili po božanskom pravu, nema trajne nasljednike u primatu nad općom Crkvom, kao i oni koji niječu da rimski prvosvećenik nije nasljednik blaženoga Petra u tom primatu. ${ }^{78}$

Treće poglavlje, koje govori o svojstvima primata rimskih prvosvećenika (De vi et ratione primatus Romani pontificis), obrađuje opis papina primata, opće nadležnosti pape, nadležnosti biskupa te predstavlja papu kao vrhovnog suca iznad kojega nema višeg priziva (primjerice, na koncil). Narav papina prvenstva, tj. primata, ističe se kroz puninu njegove vlasti da pase, vodi i upravlja cijelu Crkvu, ne samo u stvarima vjere i ćudoređa nego također i u disciplinskim i upravnim stvarima. U izvršavanju svoje dužnosti rimski prvosvećenik nije ovisan o biskupskim nadležnostima, kao ni o svjetovnoj vlasti.

Četvrto poglavlje O nezabludivom naučavanju rimskog prvosvećenika (De Romani pontificis infallibili magisterio) obrađuje dogmu papinske nezabludivosti, koju temelji na svjedočanstvu ekumenskih koncila: Četvrtom carigradskom: 869. - 870., Drugom lyonskom: 1274., i Firentinskom: 1439. godine. Opisujući karakter, narav i svrhu papinske nezabludivosti Koncil naučava i definira da se: »rimski prvosvećenik, kada govori 〈sa stolice〉 (ex cathedra), tj. kada vrši službu pastira i učitelja svih kršćana i kada svojim vrhovnim autoritetom definira učenje o vjeri i ćudoređu koje treba držati cijela Crkva, odlikuje onom nezabludivošću koja mu je obećana u blaženom Petru i kojom je božanski Otkupitelj želio da bude opremljena njegova Crkva kod učenja o vjeri i ćudoređu; zbog toga su takve definicije rimskoga prvosvećenika nepromjenjive po sebi, a ne po suglasnosti Crkve « ${ }^{79}$.

S proglašenjem konstitucije Pastor aeternus Koncil je zapravo bio tek na početku jer je preostao još 51 nacrt za raspravu, među kojima 28 disciplinske naravi. Većina tih nacrta još nije bila ni podijeljena koncilskim ocima. ${ }^{80}$

Međutim, za to više nije bilo vremena, jer se na europskoj pozornici pojavio ratni vihor koji je doveo do prekida Koncila. Naime, samo dan nakon proglašenja dogme o nezabludi-

$77 » \mathrm{Si}$ quis dixerit, beatum Petrum apostolum non esse a Christo domino constitutum apostolorum omnium principem et totius ecclesiae militantis visibile caput; veli eundem honoris tantum non autem verae propriaeque iurisdictionis primatum ab eodem domino nostro Iesu Christo directe et immediate: anathema sit«, COD, str. 812; DS, str. 597.

78 »Si quis ergo dixerit, non esse ex ipsius Christi domini institutione seu iure divino, ut beatus Petrus in primatu super universam ecclesiam habeat perpetuos successores; aut Romanum pontificem non esse beati Petri ine odem primatu successorem: anathema sit«, COD, str. 813; DS, str. 597-598.

$79 »[\ldots]$ sacro approbante concilio, docemus et divinitus revelatum dogma esse definimus: Romanum pontificem, cum ex cathedra loquitur, ide est, cum omnium christianorum pastori set doctoris munere fungens, pro suprema sua apostolica auctoritate doctrinam de fide vel moribus ab universa ecclesia tenendam definit, per assistentiam divinam, ipsi in beato Petro promissam, ea infallibilitate pollere, qua divinus Redemptor ecclesiam suam in definienda doctrina de fide vel moribus instructam esse voluit; ideoque eiusmodi Romani pontificis definitiones ex sese, non autem ex consensu ecclesiae irreformabiles esse«, COD, str. 816; DS, str. 601.

${ }^{80}$ Ipak, godine napornog rada koje su članovi pripremnih komisija posvetili izradi nacrta, kao i sami nacrti, nisu otišli u nepovrat niti su bili izgubljeni. Naprotiv, obilje te građe nekoliko je desetljeća kasnije, u pontifikatu Benedikta XV. (1914. - 1922.), bilo upotrijebljeno za izradu Codex Iuris Canononici iz 1917. godine. Usp. Francisque CIMITIER, Les sources du droit ecclésiastique, Paris, 1930., str. 139-146. 
vosti (19. srpnja) izbio je francusko-pruski rat. Mnogi su biskupi, s papinim odobrenjem, otputovali iz Rima i vratili se u svoje biskupije, ali su generalne kongregacije, unatoč tome, nastavile s radom sve do 1. rujna. Budući da je Francuska za potrebe rata s Prusijom povukla iz Rima svoje postrojbe, tu je situaciju iskoristila talijanska vlada koja je osvojila ostatke Crkvene Države (8. rujna), a naposljetku i Rim (20. rujna). Pio IX. je protestirao protiv nasilja i zatvorio se u Vatikan, a zatim bulom Postquam Dei munere (20. listopada) odgodio Koncil sine die. ${ }^{81}$

S povratkom u svoje biskupije, biskupi su, uključujući i one koji su napustili Rim i Koncil prije 18. srpnja, postupno prihvaćali odluke Koncila, objavljujući u dijecezanskim glasilima njegove odluke. Kod francuskog episkopata to je išlo brže, a kod njemačkog, austrijskog i ugarskog sporije. ${ }^{82}$ U potonju je skupinu ulazio i biskup Strossmayer. ${ }^{83}$

\subsection{Starokatolička crkva}

Jedan od onih koji je otišao iz Rima prije završnog glasovanja bio je i münchenski nadbiskup i metropolit Gregor Leonhard Andreas von Scherr († 1877.). Nakon povratka u svoju nadbiskupiju susreo se s profesorima Teološkog fakulteta te je tadašnjem dekanu Fakulteta, uglednom Döllingeru, kazao: »Stavimo se ponovno na posao za svetu Crkvu«. Döllinger je odgovorio: »Da, za staru Crkvu«. Pobijajući njegov odgovor nadbiskup mu je

81 R. AUBERT, Il pontificato di Pio IX, vol. XXI/2, str. 550-551.

${ }^{82}$ S obzirom na francuski episkopat, vidi: Giacomo MARTINA, La Chiesa dell'età del liberalismo, Morcelliana, Brescia, 1978., str. 216-218; R. AUBERT, Il pontificato di Pio IX, vol. XXI/2, str. 553-554. Što se tiče njemačkog episkopata, podlaganje koncilskim odlukama, posebno dogmi o nezabludivosti, nije teklo baš glatko, a pojedini su proživljavali čak i prave drame. Eklatantan primjer u tom smislu je rottenburški biskup Carl Joseph von Hefele, koji se posljednji podložio koncilskim odlukama (učinio je to 10. travnja 1871., devet mjeseci nakon proglašenja dogme o nezabludivosti). Kakvu je osobnu dramu proživljavao svjedoče njegove riječi da je »bolje otići na onaj svijet kao pošteni Švabo, nego davati krivo svjedočanstvo zbog ljudskog obzira«, dok je prijatelju Döllingeru kazao: »Priznati kao božanski objavljenu neku stvar koja u sebi nije istinita, neka čini tko želi, ja non possum«. Usp. H. WOLF, Storia della Chiesa cattolica nel secolo 'lungo' (XIX), str. 167-168.

${ }^{83}$ Strossmayer je posljednji prihvatio odluke Koncila (pretposljednji je bio kaločki biskup Lajos Hajnald). Donedavna se smatralo da je Strossmayer prihvatio koncilske odluke koncem 1872., no to je (i to prešutno) bilo tek u veljači 1873. Njegovo je prihvaćanje teklo drukčije od ostalih biskupa koncilske manjine. Naime, odluke Koncila objavljene su u biskupijskom glasilu početkom 1873., ali ih Strossmayer nije ni potpisao ni preporučio, nego ih je potpisalo uredništvo glasila. K tomu, Strossmayer nije dao nikakve ni javne ni pismene izjave o prihvaćanju koncilskih odluka, a početkom veljače 1873. primljen je u audijenciju kod Pija IX., gdje je učinio svoj submissio. No činjenica je da se njegovo konačno i unutarnje prihvaćanje Koncila i koncilskih odluka nije dogodilo za pontifikata Pija IX., nego tek za njegova nasljednika Leona XIII. (1878. - 1903.), točnije 1881. godine, kada je u biskupijskom glasilu dao komentar na Grande munus, encikliku Leona XIII. o Svetoj Braći Ćirilu i Metodu. Usp. A. ŠULJAK, Biskup Josip Juraj Strossmayer, str. 75; Ivo SIVRIC, Bischop J. G. Stroßmayer, New Light on Vatican, Roma - Chicago, 1975., str. 247-270. O đakovačkom biskupu u našoj su literaturi i znanstvenim zborovanjima njemu čast izrečene brojne pohvale, koje on, nedvojbeno, i zaslužuje. Međutim, s obzirom na Prvi vatikanski koncil i papu Pija IX. činjenica je da jedan od najboljih koncilskih govornika nije bio prisutan ni na jednom svečanom činu Koncila osim na njegovu otvaranju. Prilikom proglašenja konstitucije Dei Filius nije bio u bazilici sv. Petra, nego je protestno šetao oko Vatikana. Kad se izglasavala konstitucija Pastor aeternus također nije bio, jer se solidarizirao s biskupima iz koncilske manjine i otišao s Koncila prije njezina proglašenja. K tome, odluke Koncila u biskupijskom glasniku nije potpisao on, nego je to prepustio uredništvu glasnika, a njegovo prihvaćanje Koncila nije se zbilo u pontifikatu Pija IX., koji je taj Koncil sazvao, nego u pontifikatu pape koji ga je naslijedio. 
uzvratio: »Postoji samo jedna Crkva, ne postoji ni nova ni stara«. No, stari i nepomirljivi profesor je ostao pri svome izjavljujući: »Stvorena je nova! « ${ }^{84}$

Taj dijalog dvojice eminentnih ljudi tadašnjega vremena u velikoj mjeri odražava i postkoncilsko crkveno stanje u Njemačkoj, i na njemačkome govornom području, gdje su pojedine skupine vjernika, nezadovoljne odlukama Koncila, organizirale javna okupljanja i prosvjedne skupove. Jedan takav skup održan je u Münchenu od 22. do 24. rujna 1871., gdje su sudionici toga skupa odbili prihvatiti koncilske odluke te osnovali Starokatoličku crkvu (Altkatolische Kirche), odijeljenu od Rima, čiji su se pripadnici nazvali »starokatolici« (Altkatholiken), jer su smatrali da odluke Koncila nisu više odražavale Katoličku crkvu. Jedan od vođa tog prosvjednog pokreta i njegov »duhovni vođa«, prije nego se on pretočio u raskol s Rimom, bio je upravo Döllinger. Iako je odbio priznati jurisdikcijski primat i papinu nezabludivost, zbog čega ga je münchenski nadbiskup izopćio (17. travnja 1871.), on ipak nije imao namjeru »suprotstaviti oltar oltaru« niti je pristao na bilo kakvu suradnju u izgradnji autonomne »starokatoličke« crkvene organizacije. ${ }^{85}$

\section{Zaključak}

Prvi vatikanski koncil, iako prekinut prije vremena, je s povijesno-dogmatske, ustavnopravne i političko-crkvene točke gledišta bio od velike važnosti za život Crkve. Njegove dogmatske definicije u pitanju katoličke vjere, sveopćeg biskupstva i papine nezabludivosti kad naučava ex cathedra predstavljaju prirodan završetak jednog procesa koji su mnogi željeli vidjeti i u obliku dogmatske definicije. Te su definicije, uzdižući se kao prepreka sve goropadnijem i razornom nadiranju onodobnog subjektivizma, relativizma i liberalizma, s jedne, te potiskujući partikularističke težnje (galikanizma, jozefinizma, febronijanizma), s druge strane, u velikoj mjeri pridonijele ugledu papinstva - činjenica koja je bila jasna već na Koncilu, a nakon njega još i više - a ljudima pružile snažnu poruku, i jasan odgovor, u doista svakovrsnom kolopletu tadašnjih društvenih i ideoloških previranja. Premda je u svom pontifikatu s velikom tugom u srcu doživio nestanak Crkvene Države sa zemljopisne karte nakon njezina milenijskog postojanja i s teškom mukom morao prekinuti Koncil sine die, pontifikat Pija IX. ipak, bez dvojbe, ulazi u velike pontifikate crkvene povijesti, ne samo zbog njegove dužine kao najduži pontifikat u papinskoj povijesti već upravo zbog Prvog vatikanskog koncila. A razlog je sljedeći: s tim koncilom Katolička crkva dobila je znatno više nego što je s nestankom Crkvene Države izgubila. Patrimonium sancti Petri, po jednima dragocjen po drugima štetan, ipak je stoljećima predstavljao velik uteg, dok je Koncil pružio jasan odgovor na probleme tadašnjega vremena i kao takav postao sigurno uporište za daljnji hod Crkve. Rasterećen političkih i administrativnih obveza, koji su

\footnotetext{
${ }^{84}$ R. AUBERT, Il pontificato di Pio IX, vol. XXI/2, str. 558.

85 J. LENZENWEGER et al., Storia dela Chiesa cattolica, str. 600; J. LORTZ, Storia della Chiesa, str. 433; K. BIHLMEYER - H. TUECHLE, Storia della Chiesa, str. 244-246. Članovi Starokatoličke crkve su 1873. izabrali vlastitog biskupa, Josepha Huberta Reinkensa, profesora teologije u Breslau (današnji Wroclaw u Poljskoj), kojega je posvetio jansenistički biskup Heykamp iz Deventera. Iste je godine izrađen starokatolički sinodalni i župni ustav, a 1899. godine uslijedilo je stupanje u Utrechtu uniju. Time su starokatolici postali Crkva. Njezine su zajednice uglavnom nastajale na njemačkom govornom području (Bavarskoj, Austriji i Švicarskoj), no brojčano je uvijek ostala malena.
} 
nestali s nestankom Crkvene Države, papinstvo se konačno, potpuno i slobodno, moglo posvetiti svojoj izvornoj zadaći i poslanju: religioznim i crkvenim pitanjima. Prvi vatikanski koncil, sa svojim odlukama i definicijama, sadržanima u Dei Filius i Pastor aeternus, tomu je širom otvorio vrata. Iz današnje perspektive, a u prigodi 150. godišnjice njegova završetka, ta nam se konstatacija čini »nezabludivo« ispravna.

\section{SUMMARY \\ THE FIRST VATICAN COUNCIL. ON THE OCCASION OF THE $150^{\text {th }}$ ANNIVERSARY OF ITS COMPLETION}

After many years of preparation pope Pio IX assembled and opened the First Vatican Council in 1869. It was also the 20 th ecumenical council, which was held 306 years after the previous Council of Trent. About 700 delegates from all around the Globe participated in the work of the First Vatican Council. Commissions that prepared the Council created many drafts for the Council's decrees and constitutions, but the Council proclaimed only two dogmatic constitutions: Dei Filius (About the Catholic faith) and Pastor aeternus (About Christ's Church). Since the latter constitution included questions about dogmatic definition of Pope's infallibility, this constitution provoked division between those who accepted it (infallibilists) and those who rejected it (anti-infallibilists). The infallibilists were majority, but the minority did not want to accept definition of Pope's infallibility and they abandoned the Council before the voting on the constitution. Day after the voting the constitution Pastor aeternus the war between Prussia and France broke out, and the Pope had to interrupt the Council and postpone it for better days (sine die), but the Council was never resumed. When bishops returned to their dioceses, they published Council's decisions in the diocesan newspapers. Some of them were faster and some slower. One among the last was Josip Juraj Strossmayer, bishop of Bosnia and Syrmia, who was one of the best speakers at the Council but also one of the most vigilant opponents to dogma of Pope's infallibility. Decisions of the First Vatican Council were not very well accepted among some of the believers, so they consequently have abandoned Catholic Church and established the Old Catholic Church.

KEY WORDS: Pio IX, Council, commissions, constitutions, dogma, Church. 
